\title{
EL PUNTO GIEGO QUE PERMITE VER: DE LAS TEOFANÍAS MÁS ALLÁ DE LAS IMÁGENES (IBN 'ARABĪ) A LA VISIÓN EN LA EXTINGIÓN (KIAROSTAMI)
}

\section{Antoni Gonzalo Carbó}

Recibido el 08/12/16. Aceptado el 16/01/17.

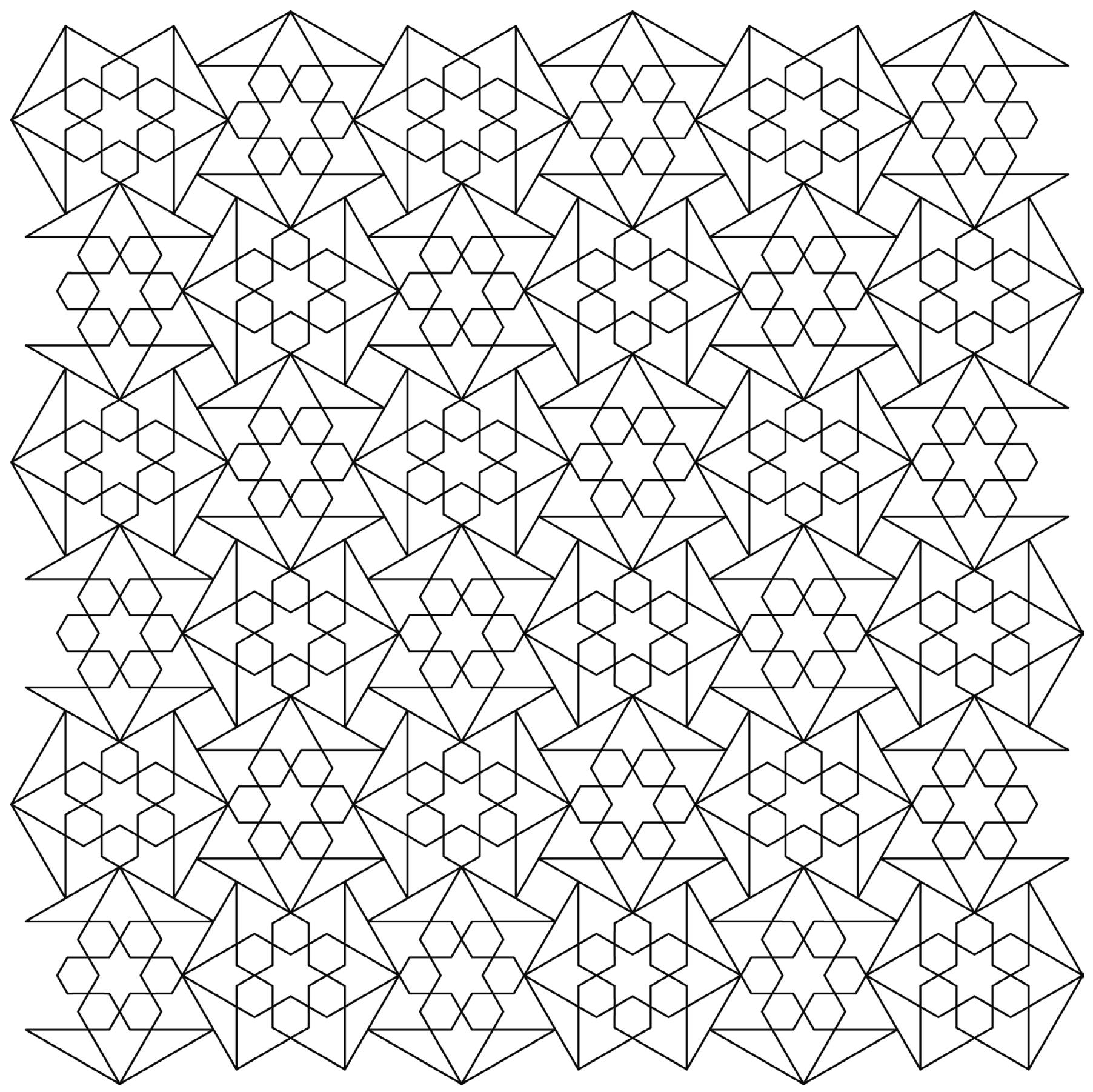


«La imposibilidad de percibir es ya una percepción (al-'ăgaz'an darak al-idrāa $i d r a ̄ k) . »$

Célebre dicho de Abū Bakr citado por Ibn 'Arabī.

«Si Me encuentras no Me verás, mas Me verás si Me pierdes.»

Ibn 'Arabī, Mašāhid al-asrār (Las Contemplaciones de los misterios), cap. I, trad. de Suad Hakim y Pablo Beneito.

«Quand, le soleil perçant déjà, la rivière dort encore dans les songes du brouillard, nous ne la voyons pas plus qu'elle ne se voit elle-même. Ici c'est déjà la rivière, mais là la vue est arrêtée, on ne voit plus rien que le néant, une brume qui empêche qu'on ne voie plus loin. A cet endroit de la toile, peindre ni ce qu'on voit parce qu'on ne voit plus rien, ni ce qu'on ne voit pas puisqu'on ne doit peindre que ce qu'on voit, mais peindre qu'on ne voit pas, que la défaillance de l'œil qui ne peut pas voguer sur le brouillard lui soit infligée sur la toile comme sur la rivière, c'est bien beau.»

Marcel Proust, Fean Santeuil, (a propósito de un lienzo de Claude Monet).

«[... La niebla de la propia percepción de la mirada [...]. Que el exceso de luz impida una visión clara; $[. .$.$] se trata de recibir esa misma luz [...]. Erigir el medio invisible en$ objetivo visible $[\ldots] »$.

Jean-Luc Marion, El cruce de lo visible, (a propósito de Claude Monet).

«La forma más pura es para siempre aquella

que ha penetrado la bruma que se borra»

Yves Bonnefoy, Principio y fin de la nieve.

«La pintura es un ojo, un ojo cegado que continúa viendo, que ve lo que lo enceguece». Bram van Velde.

«El santo alzó la vista, y la oración / cayó, cabeza atrás, igual que un casco: / pues sin ruido llegaba el increíble / blanco animal [...] // blanco fulgor [weißer Glanz] $[\ldots] »$.

«Los ojos, tras los párpados, se han dado / la vuelta, y ahora miran hacia dentro».

«Ya no existo. Algo [...] / que no han visto mis ojos. Me ha eclipsado la luz»

«Apágame los ojos: puedo verte».

Rainer Maria Rilke, «El unicornio»; «Morgue» (Nuevos poemas), El libro de horas. 
«en el punto donde no se ve».

«[...] un ojo [...] cegador, / donde la luz es sólo la extensión».

José Lezama Lima, «Himno para la luz nuestra» (Dador); «El pez y los ojos» (Fragmentos a su imán).

«Un rostro con los ojos vendados por el negro velo de la mirada».

«Augen, weltblind $[\ldots] »$ («Ojos, al mundo ciegos $[\ldots] »)$

«A la ceguera con- / vencidos ojos.»

«Ciégate para siempre: / también la eternidad está llena de ojos - / allí / se ahoga lo que hizo caminar a las imágenes».

Paul Celan, «Poema para la sombra de Mariana»; «Schneebett» (Lecho de nieve), Sprachgitter (Reja de lenguaje); «Tübingen, Jänner» (Tubinga, enero), Die Niemandsrose (La rosa de nadie); Atemwende (Cambio de aliento).

«Usted intentará mirar hasta la extinción de la mirada, hasta su propia ceguedad y a través de ésta deberá intentar aún mirar. Hasta el final».

Marguerite Duras, El hombre atlántico.

«En esta lengua de imágenes es preciso perder por completo la noción de imagen, que las imágenes excluyan la idea de imagen.»

Robert Bresson, Notas sobre el cinematógrafo.

«Entonces se crea un gran deslumbramiento ciego, una extinción de las cosas vistas. [...] Ver supone la aniquilación de toda cosa vista.»

Michel de Certeau, «Éxtasis blanco».

\section{1. «LOS OJOS TRAGADOS»}

Disolverse en la visión, aniquilarse en el reverso de la pupila, deslumbramiento hasta confundirse con el propio blanco del ojo: «ein weißer Glanz», «un blanco fulgor» («Das Einhorn», Rilke). Todo ello queda muy bien expresado en la imagen de «los ojos cerrados (die Augen geschlossen)», los «ojos tragados (verschluckten Augen)» de otro poema de Rilke («Improvisationen aus dem Capreser Winter»). En este último, por tres veces repite el poeta la idea de dejamiento: laß («déjame»). Fulguraciones visionarias 
aniquilantes. En este sentido, el también poeta René Char nos habla de una «mort éclairante» ${ }^{1}$ y la pensadora María Zambrano de «una muerte aurora, señal del sacrificio aceptado» ${ }^{2}$. La desaparición de sí en el Otro de sí: disolución (mahwe)/extinción $(f a n \bar{a})$ del yo fenoménico (sufismo), blanche agonie (blanca agonía), pur éclat (puro destello) (Mallarmé), la «abolición» (Mallarmé, J. Á. Valente), effacement (Edmond Jabès), éclat: en su doble sentido: lo que estalla y lo que ilumina; «éclair-éclat», a un tiempo aniquilando las cosas del campo de la visión y anonadando al instante al testigo de contemplación (Michel de Certeau)...

$\mathrm{Al}$ igual que en la obra poética de Mallarmé/Valente («abolición»), Rilke («la gran muerte»), o Jabès (effacement), en la escritura de Marguerite Duras esta imagen de la borradura de sí (effacement $)^{3}$ por medio del ojo cegado que continúa viendo aparece varias veces. La lividez agotadora de una luz absoluta que domina las cosas sin bañarlas, abrumadora, cruelmente aterradora («el espantajo de la luz» $»^{4}$, luz aguda, que hiere con su filo relumbrante los ojos de Anne-Marie Stretter «rotos de luz, muertos $\iota^{5}$, agrediendo y desgarrando los de Lol: «Lo veo todo. Incluso el amor. Los ojos de Lol están apuñalados por

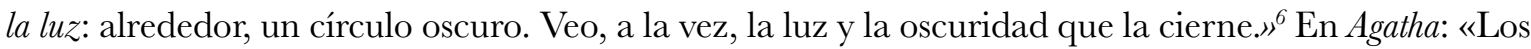
ojos están invisibles. El cuerpo está por entero encerrado bajo los párpados.» " "No hemos de creer que la ausencia esté desprovista de imágenes. Sin ellas, no la podríamos concebir” (Jabès). [...] Para que la luz vuelva a ser sustancia del mundo, gracias a la transparencia de la imagen cinematográfica, era necesario que Duras acarrease con ese poder de muerte, el aniquilamiento del aniquilamiento, no la idolatría moderna de la obra de arte, sino "el pensamiento en blanco" (O. Paz) [...]. Nos encontramos antes sus filmes como en el intersticio entre la utopía y la imagen, "imagen de una imagen, representación de un irrepresentable en búsqueda de sí mismo", a la escucha de una palabra dirigida al Otro, palabra de Nada, de silencio, de olvido: un ver abismándose en el ver. [...] La imagen es necesaria para que sepamos de la ausencia. Pero desde la imagen, la ausencia se reincorpora a ella misma. "Y si la ausencia fuese un pensamiento - un pensamiento de la ausencia" (Jabès).. ${ }^{8}$

1 R. Char, «Crésus», Le marteau sans maître. Cf. S. Velay, L'éblouissement et la fureur, París: Olbia, 1998, p. 47. Para el contexto de la poesía sufi véase É. Geoffroy, Un éblouissement sans fin. La poésie dans le soufisme, París: Seuil, 2014.

2 M. Zambrano, «Hombre verdadero: José Lezama Lima» (1977), en La Cuba secreta y otros ensayos, Madrid: Endymion, 1996, pp. 176, 180.

3 Cf. B. Alazet, Le navire night de Marguerite Duras: écrire l'effacement, Lille: Presses Universitaires de Lille, 1992; D. Bajomée, «La nuit, l'effacement, la nuit», en D. Bajomée; R. Heyndels (comp.), Écrire dit-elle. Imaginaires de Marguerite Duras, Bruselas: Éditions de l’Université de Bruxelles, 1985, pp. 85-98.

4 M. Duras, Le navire Night, París: Mercure de France, 1979, p. 10.

5 M. Duras, India Song, Barcelona: Fontamara, 1974, p. 41.

6 M. Duras, El arrebato de Lol V. Stein, Barcelona: Tusquets, 1987, p. 86. (El subrayado es nuestro).

7 M. Duras, Agatha, Madrid: Ediciones del Oriente y del Mediterráneo, 1994, p. 60.

8 Y. Ishaghpour, «La voz y el espejo», en J. Magny (et al.), Marguerite Duras. El cine del desgarro, Valencia: Ediciones de la Mirada, 1997, pp. 81, 91, 93. 
En el contexto de la tradición, esta luz excesiva es la que fulmina a Moisés en el Monte Sinaí, la luz divina que deslumbra el entendimiento y aniquila al testigo de la contemplación? ${ }^{9}$

En el cinematógrafo las imágenes de la locura de la luz llevada a los ojos son frecuentes. Tomemos como referencia siete significativos ejemplos de ojos sacrificados a la luz.

1.- En primer lugar, el plano final del cuerpo muerto de la golfa (La chienne, 1931, Jean Renoir) tendido en el lecho, nimbado de una excesiva luz de santidad en la abyección, mirando fijamente hacia la ventana, único exitus de luz ${ }^{10}$. Estas dos jóvenes - una prostituta: Lulú (La golfa, 1931, Jean Renoir) y una artista de music-hall: Champagne Ivy Pearson (Dr. Feckilly Mr. Hyde, 1931, Rouben Mamoulian)-, muestran, en ambos filmes, realizados en el mismo año, un rostro similar de éxtasis a través de la muerte (la «muerte en vida la has trocado» de Juan de la Cruz): mientras el cuerpo cae, exánime, la luz asciende, ingrávida.

2.- Otro cuerpo horadado por la luz es el de la joven Léone (Vampyr, 1932, Carl Theodor Dreyer) ${ }^{11}$. Nos referimos en concreto al bellísimo primer plano de la mano del doctor levantando el párpado de la joven (que, en inclinación ex-tática del rostro lívido, transita hacia lo invisible intoxicada por el deseo de morir: sólo vemos un ojo en blanco, esclerótica sin pupila, ojo en forma de herida abierta de luz (véase la fotografía anexa) ${ }^{12}$. Esta esclerótica sin pupila es el «blanco sobre blanco imposible de filmar» (C. Th. Dreyer) o el «construye tu película sobre lo blanco» (Robert Bresson), blanco sobre blanco (Lezama Lima ${ }^{13}$, Maurice Blanchot). «El espectro - escribe Derrida haciendo referencia a la teología negativa-, como su nombre indica, es la frecuencia de cierta visibilidad. Pero la visibilidad de lo invisible. Y la visibilidad, por esencia, no se ve, por eso permanece epekeina tes ousias, más allá del fenómeno o del ente. El espectro también es, entre otras cosas, aquello que uno imagina, aquello que uno cree ver y que proyecta: en una pantalla imaginaria, allí donde no hay nada que ver. Ni siquiera

9 Frente a la zarza que arde sin consumirse (Éx 3:6) Moisés debe cerrar los ojos ante una imagen que desborda la visión, la Faz sin rostro que ciega la visión, que es la presencia misma de lo invisible, de lo no representable, oclusión o ablepsia de la mirada que constituye el principio de la visio mystica. Cf. M. Gerhart, «The World Image Opposition: The Apophatic-Cataphatic and the Iconic-Aniconic Tensions in Spirituality», en A. W. Astell (ed.), Divine Representations. Postmodernism and Spirituality, Nueva York; Mahwah: Paulist Press, 1994, pp. 63-79; B. C. Lane, «Sinai and Tabor: Apophatic and Kataphatic Symbols in Tension», Studies in Formative Spirituality, n. ${ }^{\circ}$ 14:2 (1993), pp. 189-205; E. R. Wolfson, Giving Beyond the Gift. Apophasis and Overcoming Theomania, Nueva York: Fordham University Press, 2014, «1. Via Negativa and the Imaginal Configuring of God», «2. Apophatic Vision and Overcoming the Dialogical», pp. 14-33, 34-89, indice s.v. «burning bush».

10 Cf. J.-L. Leutrat, «La Chienne» de Jean Renoir, Crisnée: Yellow Now, 1994.

11 Cf. J. Aumont, Vampyr de Carl Th. Dreyer, Crisnée: Yellow Now, 1993; D. Bordwell, The Films of Carl-Theodor Dreyer, Berkeley: University of California Press, 1981, pp. 93-116.

12 J. Aumont, Vampyr de Carl Th. Dreyer, o.c., «La couleur des fantômes», pp. 28-9.

13 «Blanco sobre blanco, y en el blanco, blanco. Pongo mis manos sobre el hielo, pero después no puedo recogerlas.» (6 de junio de 1947). J. Rodríguez Feo, Mi correspondencia con Lezama Lima, México: Ediciones Era, 1991, p. 70 . 
la pantalla, a veces; y una pantalla siempre tiene, en el fondo, en el fondo que ella es, una estructura de aparición desapareciente. [...] Una vez más, hay que invertir la perspectiva: fantasma o (re)aparecido, sensible insensible, visible invisible, el espectro primero nos ve. Del otro lado del ojo, cual efecto visera, nos mira antes incluso de que le veamos o de que veamos sin más. Nos sentimos observados, a veces vigilados, por él, incluso antes de cualquier aparición. Sobre todo ${ }^{-}$y éste es el acontecimiento-, porque el espectro es acontecimiento, nos ve durante una visita. Nos hace visitas. Visita tras visita, puesto que vuelve a vernos y que visitare, frecuentativo de visere (ver, examinar, contemplar), traduce perfectamente la recurrencia o re(aparición), la frecuencia de una "visitación".»" ${ }^{14}$

En este sentido, el poeta Paul Celan nos habla de un «perfil blanco, que no posee otra cosa que un ojo sin pupila y que precisamente porque no posee más que eso, puede y sabe más que nosotros» ${ }^{15}$. Quizás Dreyer, por medio de este ojo en blanco, todo esclerótica sin pupila, haga referencia al ojo que nos mira y por el que vemos, «blanco sobre blanco» (Weiß in weiß), según el verso de Paul Klee ${ }^{16}$.

Mirada inolvidable de aquella que, en el guión de Vampyr, pasa por ciega. Para la presentación de este filme de Dreyer, Charles Tesson escogió como epígrafe el paso más emotivo del argumento: «Ella [la vampira Marguerite Chopin, la anciana del cementerio] se inclina con su rostro cruel por encima del cristal [del ataúd del joven Allan Gray] con la luz de la vela. Sus ojos ciegos no pueden ver al muerto, pero él [a través del cristal] sí puede verla a ella.» ${ }^{17}$ Ella no puede ver al muerto, pero el muerto (la muerte) sí puede verla a ella con claridad. En el campo del cine, el punto ciego es ese afuera, ese fuera de campo, invisible, y sin embargo narrativo, que descarga todo su peso sobre los intersticios, las elipsis, las fisuras. A la sombra de estas asociaciones, diferenciaciones y espaciamientos, existe un todo. Un todo tras las anteojeras que dejan entrever algo indiscernible: ver amanecer la noche, la luz blanca en la oscura, la vigilia en el sueño, el mundo imaginal (Tabú, F. W. Murnau; Vampyr, C. Th. Dreyer); el blanco sobre blanco (C. Th Dreyer, Marguerite Duras, Philippe Garrel...).

En Vampyr, todo es mirada ciega.

3.- Otro primer plano del rostro, el del poeta (La sangre de un poeta, 1930, Jean Cocteau), que extático cae, como el de Léone, con unos ojos pintados encima de los párpados, los ojos cerrados que aparentan estar abiertos, ojos desdoblados, ojos como incrustados mirando al más allá, ojos rectificados (desmedidamente abultadas las escleróticas y las pupilas pintadas por el globo ocular): es la disolución

14 J. Derrida, Espectros de Marx. El Estado de la deuda, el trabajo del duelo y la nueva Internacional, Madrid: Trotta, 1995, p. 117.

15 P. Celan, «Edgar Jené y el sueño del sueño», en Obras completas, trad. de J. L. Reina Palazón, Madrid: Trotta, 1999, p. 473. (La cursiva es mía).

16 P. Klee, «Traum» (Sueño), Poemas, trad. de A. Sánchez Pascual, Barcelona: Ediciones de la Rosa Cúbica, 1995, pp. 64-5.

17 C. Th. Dreyer, argumento de Vampyr, en C. Th. Dreyer, Euvres cinématographiques 1926-1934, pres. y nn. de M. Drouzy; Ch. Tesson, Grenoble: Cinémathèque française, 1983, pp. 93, 100, 139. 
de la pupila en el blanco del ojo (de lo invisible). Este bello plano nos evoca la imagen de los ojos cerrados (Augen geschlossen), los ojos tragados (verschluckten Augen), del mencionado poema de Rilke:

$$
\begin{aligned}
& \text { «Déjame, déjame, con los ojos cerrados, } \\
& \text { como tragados, déjame, }[\ldots] \\
& \text { aguardar en tu borde a que este vértigo } \\
& \text { con que yo me disuelvo } \\
& \text { devuelva a su lugar } \\
& \text { mis sentidos raptados.» }^{18}
\end{aligned}
$$

4.- El poeta enamorado de la muerte (Orfeo, 1950, Jean Cocteau), la muerte enamorada de él, y, dándole la vuelta a la mitología, ella puede mirar, pero no poseer lo que mira. Un amor imposible que trasciende los propios límites de la vida, tras la cual existe otro mundo en el que la muerte es un emisario más, al servicio de un poder, mayor que dicta las leyes en el inframundo. La muerte, que en la película recibe el nombre de la Princesa (María Casares), tiene las pupilas desmesuradamente grandes y oscuras: la muerte de la luz, el revés de la pupila.

5.- Ojos fulminados, los del santo que no teme ser aniquilado por la otra luz, o los de Roma Courtney (Supernatural, 1933, Victor Halperin), que lleva la transformación resplandeciente en sus pupilas ciegas. Lezama Lima escribe en este sentido: «El ojo se hace tan transparente que parece que nos quedamos ciegos» ${ }^{19}$. Un primerísimo plano nos muestra los ojos de Roma Courtney (Carole Lombard) mirando al espectador. En este plano, que se sitúa en el contexto de una sesión de espiritismo, un rayo de luz incide sobre la esclerótica de la joven, blanco sobre blanco, ojos que se tornan casi translúcidos en un ejercicio de atención hipnótica a la luz ciega de lo sobrenatural. «Figuras que la visión apetece en su ceguera $[\ldots]$ una blancura no vista $[\ldots] »^{20}$.

«¿Quién / es lo bastante invisible / para veros?» [wer / ist unsichtbar genug, / euch zu sehen?]», se pregunta Paul Celan ${ }^{21}$. María Zambrano añade: «Perdido en la riqueza, ciego en la luz» ${ }^{22}$. Antonio Gamoneda apunta en la misma dirección que nuestra pensadora: «Yo, sin ojos, te miro transparente» ${ }^{23}$;

18 R. M. Rilke, «Improvisaciones del invierno en Capri [1]» en R. M. Rilke, Poesía, trad. de J. M. ${ }^{a}$ Valverde; ed. de J. Llovet, Castellón: Ellago, 2007, p. 409.

19 J. Lezama Lima, «Las siete alegorías», Fragmentos a su imán, Barcelona: Lumen, 1978, p. 112.

20 M. Zambrano, Claros del bosque, Barcelona: Seix Barral, 1977, p. 13.

21 P. Celan, Cambio de aliento, en Obras completas, o.c., p. 245.

22 M. Zambrano, Filosofia y poesía, México: Fondo de Cultura Económica, 1987 [1939], p. 64.

23 A. Gamoneda, Sublevación inmóvil, en Esta luz. Poesía reunida (1947-2004), Barcelona: Galaxia Gutenberg; Círculo de Lectores, 2004, p. 59. 
«Ciego en la luz, absorto en la inexistencia» ${ }^{24}$; «cuándo estaremos ciegos / en luz» ${ }^{25}$.

6.- Mirada que lleva la muerte en los ojos. Ojos aniquilados, deslumbramiento ciego: fotograma de los ojos vaciados de un hombre en el bosque, en el episodio del cegamiento del filme Andrei Rublev (1966), de Andrei Tarkovski ${ }^{26}$. Ojos vacíos por la oscuridad constitutiva: «Una imagen -escribe Tarkovski- es... una impresión de la verdad a la que podemos dirigir nuestra mirada desde nuestros ciegos ojos.» ${ }^{27}$ En Offret (Sacrificio, 1986), su testamento cinematográfico, Otto, el cartero del pueblo, afirma: «Miramos, pero no vemos nada». La luz boreal del filme es una blanca pantalla que ciega. Es la imagen de una conversión radical a otro modo de ver. Este plano nos evoca cuatro líneas de José Ángel Valente: «Era necesario taladrar el espesor de la luz para empezar a ver.» ${ }^{28}$ «La ceguera es la mirada del vidente, del que realmente ve.» «La forma que lo invisible toma en la mirada es la de su pérdida.» ${ }^{29}$

7.- Por último, la mirada autocegada (Edipo Rey, 1967, Pier Paolo Pasolini) es la mirada del que realmente ve. Edipo, ciego y mendigo, se halla ante un prado verde, verde, y ante tal paisaje invisible evoca estas palabras: «Oh, luz que ya no veré, que antes era mía en alguna forma, ahora me iluminas por última vez. He llegado. La vida termina donde comienza.» Un vagar a la búsqueda de la propia identidad. Y resulta que, cuando se descubre, ningún Edipo es capaz de enfrentarse a ella y prefiere negarse la visión. En Medea y en Edipo Rey encontramos una complementariedad muy trágica entre el «ver», la «videncia», de Medea, y la ceguera de Edipo. La ceguera de Edipo, quien recupera la vista - la vista de Tiresias, la vista del que ve más allá del destino- precisamente cuando pierde los ojos, viene señalada repetidamente a través de indicios y motivos. El primer indicio es el hecho de no poder recordar un sueño: lo que le decía una voz en ese sueño. Los siguientes son más gráficos: la mano de Edipo intentando apartar el sol de sus ojos ante el oráculo, la pérdida parcial de la visión tras esa revelación, el apartar la vista de la mujer que se le presenta en medio del laberinto al que le conducen unos enigmáticos personajes del pueblo; la voluntad, en fin, de no saber, que le lleva a empujar violentamente a la esfinge al fondo del abismo, de no querer ver, que le lleva a arrancarse los ojos. El sol, abiertamente relacionado con la capacidad de «ver» de Medea, aparece en Edipo Rey como

24 Ib., p. 72.

25 A. Gamoneda, «Incandescencia y ruinas», Sublevación inmóvil.

26 Cf. A. Tarkovski, Esculpir en el tiempo. Reflexiones sobre el arte, la estética y la poética del cine, Madrid: Rialp, 1991, p. 214; K. Rogulski, «Les Voix dans les ténèbres: La symbolique de Stalker d'Andreï Tarkovski dans la lumière de l'Apocalypse», L'Avant-Scène Cinéma, n. ${ }^{\circ} 227$ (1993), pp. 3, 5-6.

27 A. Tarkovski, ib., p. 128.

28 J. Á. Valente, «El regreso», El fin de la edad de plata, en Obras completas I. Poesía y prosa, ed. de A. Sánchez Robayna, Barcelona: Galaxia Gutenberg; Círculo de Lectores, 2006, pp. 719.

29 J. Á. Valente, «El ojo de agua», La piedra y el centro, en Obras completas II. Ensayos, ed. de A. Sánchez Robayna; recop. e intr. de C. Rodríguez Fer, Barcelona: Galaxia Gutenberg; Círculo de Lectores, 2006, p. 314 n. 1; «La mirada de Orfeo», Notas de un simulador, ib., p. 472. 
motivo constante, pero con valor inverso: es exceso de luz; es el sol presente con fuerza en la escena del oráculo - tanta que apenas le deja ver a la pitia-, y en las deformadas subjetivas de Edipo mientras se aleja de allí; presente de nuevo, hasta impedir al espectador apreciar lo que ocurre en la pantalla, durante la matanza de Layo y su escolta en la encrucijada del camino ${ }^{30}$. De nuevo recurrimos a unas esclarecedoras líneas de Valente:

«¿Cómo pintar el no ver? ¿Cómo hablar de las imágenes desde el vacío de su visión? [...]

Pero ¿qué realidad buscamos o qué realidad nos reservan los no visibles trazos y colores?

Siempre pensé que escribir era entrar en el hondo misterio de lo no visible. $[\ldots]$

Secreta naturaleza del no ver. Tentar. Entrar a tientas en los oscuros corredores donde todo hallazgo es, a la vez, infinitamente posible e imposible. “¡Oscuridad, mi luz!”, decía Edipo ya autocegado.

[...] Tender un puente a ciegas sobre la visibilidad de lo invisible..» ${ }^{31}$

En este sentido, ¿cómo conciliar los ojos tapiados y los ojos deslumbrados de los que nos habla Rilke? Ceguera reveladora, ojos ahogados en la espesura de la luz. El alma incapacitada de mirar algo ${ }^{32}$, obnubilada por el resplandor, oscureciente luz.

Ver para hacer presente la presencia (in)aparente del totalmente Otro (Emmanuel Levinas), del Extranjero (Louis Massignon), del silente (Michel de Certeau), del ser ausente (Jacques Derrida), pues «la epifanía de lo absolutamente otro es el rostro; y en él el Otro me interpela»(Levinas). Las teofanías más allá de las imágenes (Ibn 'Arabī) se revelan allende del mundo de las formas: tanto más se develan aquellas a medida que se apagan estas. «Luz - escribe María Zambrano, pensadora profundamente influida por el sufismo- que al encenderse anuncia su extinción [...]. Imagen real de algo primero y nunca visto.» ${ }^{33}$

30 Cf. F. González, El tiempo de lo sagrado en Pasolini, Salamanca: Ediciones Universidad de Salamanca, 1997, pp. 200-1.

31 J. Á. Valente, «Sobre la visibilidad de lo invisible», en Obras completas II. Ensayos, o.c., pp. 1611-2.

32 «Pues algunos se echan a perder los ojos, a no ser que en el agua o en algún otro medio semejante contemplen la imagen del sol.» Platón, Fedón, 99d. Cf. el célebre símil de Rep. VII, 515e-516b. Cf. asimismo Rep. VII, 518a. Véase a su vez Plotino: «ver sin ver nada». Enn. V:5:7. Para Gregorio de Nisa se trata de «ver, en la misma imposibilidad de vern. De vita Moysis, II:163. También en el conocido episodio de Saulo y su visión-ceguera en el camino de Damasco: «con los ojos abiertos, nada veía» (Hech. 9:8).

33 M. Zambrano, De la aurora, ed. de J. Moreno Sanz, Madrid: Tabla Rasa, 2004, «La llama». 
Imágenes que se ahogan en la mirada. Los ojos están - en palabras de Paul Celan-zur Blindheit überredete: persuadidos a la ceguera, a la ceguedad: el deslumbramiento-anegamiento. Ojos ciegos al mundo, ojos en las grietas de morir, cicatrices en lugar de la vista. Tal como apunta nuestro gran poeta Antonio Gamoneda:

«Yo ciertamente repito muchas veces la palabra "vi", o la palabra "veo", quizás más en pretérito; "vi", en presente. Yo pienso que esto consiste en que mi memoria es predominantemente visual. Hay otra posibilidad, que es el ver en el sentido visionario, es decir, atravesando la alucinación. Es ése el objeto supuestamente visible para mí, es un decir. No puedo proporcionarlo con calidad de testimonio para el lector. Pertenece a la zona inexplicable de mi escritura: ver lo que no se puede ver.» ${ }^{34}$

El gran místico y poeta andalusí Muhỵī l-Dīn Ibn (al-)‘Arabī (m. 638/1240), considerado como el más grande de los místicos musulmanes -también llamado al-Šayh al-Akbar (Máximo maestro), en la última teofanía luminosa del Kitāb al-Tağalliyàt (El libro de las teofanías) ${ }^{35}$, teofanía 75 de la «luz de lo invisible» (nūr al-gayb), luz apofática, en conversación con el eminente místico y teólogo Sahl Tustarī (m. 283/896), le dice a éste enmudecido: «La respuesta conveniente ¿no es únicamente el silencio?» ${ }^{36}$. Pues si Dios se vuelve accesible en forma de luz, siendo Él mismo la fuente de la luz, no puede ser aprehendido más que por la via negationis. Imaginar sin imágenes (bildlos gebilden) según la vía de los místicos alemanes renanos.

En su magnum opus, al-Futūhàt al-makkiyya (Las iluminaciones de La Meca), expresa este desapego místico de las imágenes: «Cuando se da a contemplar, Él no te habla, y cuando Él te habla, Él no se da a contemplar a no ser que no se trate de una teofanía en una forma.» ${ }^{37}$ Formulación que implica, evidentemente, la posibilidad de una teofanía o contemplación supraformal, tal como apunta el poeta Edmond Jabès en una línea: «"Todo gesto de Dios es silencioso y por eso está escrito”, enseñaba un sabio.» ${ }^{38}$

34 Palabras recogidas en el documental Antonio Gamoneda. Lenguaje y alquimia, 2007, dir. Enrique Corti; César Rendueles, Instituto Cervantes. (La cursiva es mía).

35 Editado en Rasā'il Ibn al-'Arabī, 2 vols., Hayderābād-Deccan: The Dāiratu l-Ma'ārifi l-Osmania, 1948; O. Yahia ha publicado una edición crítica de esta obra, acompañada del Comentario de Ibn Sawdakin, en $\mathrm{Al}$ Mašriq, 1966-7. Véase la trad. franc.: S. Ruspoli, Le livre des théophanies d'Ibn 'Arabī, intr., coment., trad. y nn. del Kitāb al-Tağalliyāt, París: Les Éditions du Cerf, 2000.

36 Para la regla del silencio, véase Muhỵì l-Dīn Ibn 'Arabī, al-Futūhāt al-makkiyya (en adelante: Fut.), El Cairo 1329/1911; reimpr. Beirut: Dār al-Ṣādir, s.d., ed. de O. Yahya, El Cairo: Al-Hay'a al-Miṣriyya al-'Āmma li-lKitāb, 1392/1972, I, 277, 278. En las estaciones superiores del tawhīd, en presencia de la Divinidad inefable, el intelecto ya no puede discurrir, pues en el umbral de lo invisible ya no hay nada que decir ni describir. Cf. $L e$ livre des théophanies d'Ibn Arabī, o.c., p. 202.

37 Fut. I, p. 397.

38 E. Jabès, «Langue source langue cible», Le livre du partage, París: Gallimard, 1987, p. 46. 
Ya no hay nada que ver ahí. Los pájaros, como las cigarras, cantan. Por eso el cineasta francés Robert Bresson le había dicho a Jean-Luc Godard que cada vez que podía reemplazar una imagen por un sonido lo hacía, y que lo hacía cada vez más ${ }^{39}$.

«Blanche agonie... pur éclat (blanca agonía... puro destello)» (Mallarmé), «éxtasis blanco», «deslumbramiento ciego», (Michel de Certeau), ceguera reveladora en forma de luz, que aun siendo en sí invisible, por medio de la cual se puede ver.

Pierre Boulez, el gran compositor y director de orquesta francés, en el libro titulado Webern en doce notas, dice: «La brevedad, el silencio, la melodía de los timbres, no son procedimientos técnicos». Esto es muy importante, porque se habla mucho de la técnica de los artistas. Pero, tal como nos recuerda el gran cineasta franco-suizo Jean-Luc Godard en sus Histoire(s) du cinéma (1988-98): «El cine no es un arte ni una técnica, sino un misterio». Pues esos procedimientos, para Pierre Boulez - a propósito de la música de este gran, formidable músico que es Anton Webern- no son procedimientos técnicos, sino procedimientos casi espirituales y tienen valor de ascesis, casi de ascetismo. Influencia sorda del Oriente en la obra de Webern.

Al-Šayh al-Akbar escribe en un notable escrito de juventud, el Kitāb al-Isfàr 'an natā' iğ al-asfàr (El libro de la develación de los efectos de los viajes $)^{40}$ : «Todos los seres se hallan en la nube, reposando en la ceguera, y el todo está hecho a imagen del todo. En su espíritu y su significado, este viaje es el del paso de la

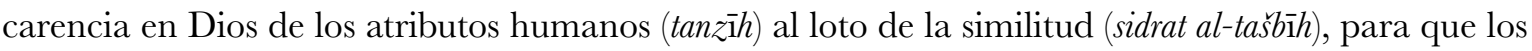

39 R. B.: -Pero me gusta más hacer que lo imaginen con ayuda de un sonido, porque siempre que puedo reemplazar una imagen con un sonido, lo hago. Y lo hago cada vez más seguido.

J.-L. G.: - ¿Y si pudiera reemplazar todas las imágenes por sonidos? Quiero decir. Pienso en una suerte de inversión de las funciones de la imagen y el sonido. Podríamos tener imágenes, por supuesto, pero el sonido sería el elemento importante.

R. B.: -Es cierto que en este aspecto el oído es mucho más creativo que el ojo. El ojo es perezoso. El oído, por el contrario, inventa, está mucho más atento en todo caso, mientras que el ojo se conforma con recibir, salvo en los casos excepcionales en los que inventa, pero entonces lo hace en la fantasía. El oído es un sentido mucho más profundo y evocador.

R. Bresson, Bresson por Bresson: entrevistas (1943-1983), Buenos Aires: El cuenco de plata, 2014.

En esta preferencia sensorial se puede intuir una profunda huella cristiana. A Dios no se lo ve, se lo escucha. Por eso es decisivo el capítulo dedicado a El proceso de fuana de Arco. El fervor del director por el personaje es absoluto. «Al parecer, fue un ser más perfecto que nosotros, más sensible. Ve sus voces. Nos convence de un mundo al límite de nuestras facultades.» Frente al anquilosamiento formal y estético del cine hollywoodiense, Bresson aboga por un estilo narrativo y de puesta en escena caracterizado por la economía absoluta en la mostración. El sonido, en lo posible, no ha de acompañar a la imagen si redunda en lo que ésta ya nos enseña. Por el contrario, y esta idea la lleva Bresson hasta las últimas consecuencias, la banda sonora ha de ser capaz de generar en la mente del espectador los espacios a los que la imagen no llega: «Cuando un sonido puede reemplazar una imagen, suprimirla o neutralizarla. El oído va más hacia adentro, el ojo más hacia afuera.» R. Bresson, Notas sobre el cinematógrafo, Madrid: Árdora, 1997, p. 57.

40 Rasā'il Ibn al-'Arabì, o.c., pp. 456-502. 
llamados puedan comprender, y aun esto muestra también la (mencionada) ceguera.» ${ }^{41}$ En la mayor parte de los manuscritos de Ibn 'Arabī, los términos 'amā' (la Nube oscura, opaca, el velo teofánico absoluto del Absconditum, el Dios oculto) y 'amā (sin la hamza final: ceguera) -que, en ambos casos, hacen referencia a la divinidad inaccesible- tienen una ortografía idéntica ${ }^{42}$.

Casi al final de uno de los capítulos más significativos de las Futūhāt al-makkiyya, el titulado Kìmīyā’ alsa'ā da (La alquimia de la bondad perfecta), en el viaje místico que conduce hacia la «Nube divina» ('amā') - el velo teofánico supremo, matrix mundi y toda primera localización metafísica concebible--, el viajero se encuentra con los Nombres del Absconditum o la via negationis ${ }^{43}$. En el cap. 78 de sus Fut., Ibn 'Arabī se refiere a la halwa, esto es, la vuelta, en la subida hacia Dios, al Vacío original (al-halā'), palabra de la misma raíz), es decir, a la Nube opaca, Nube primordial (al-'amā’) donde, según un hadiz Dios permanecía «antes de crear la creación» ${ }^{44}$. Idea que al-Ǧīlī recoge cuando plantea -como Dionisio o Gregorio de Nisa- la «ceguera» ('amā) o tiniebla primordial para hablar del aspecto inaccesible de la divinidad, la Esencia divina per se. La Nube primordial ( $a l^{-}$' $a m a \bar{a}$ '), es el ente más cercano a Dios (Fut. II, 310), el velo absoluto del Absconditum. Su estado es descrito por Ibn 'Arabī como el de una «fina neblina» (sahāb raqīq) pero ya diferenciada (Fut., ib.). Tanto al-Ǧìlī como Ahmad al-Tiğānī hablan de esta Nube como la «oscuridad» ('amā) o aspecto interior de la esencia supraontológica (al-dāa $t$ ). Nube o soplo exhalado en el Ser divino (en la haqũqa del Haqq) y en la que él mismo estaba primordialmente, resulta de la condensación del Suspiro de la Compasión divina existenciadora (nafas al-rahmān, nafas raḥmā $\overline{\mathbf{1}})$. La Nube ${ }^{45}$ es mediadora entre la Esencia divina abscóndita (al-d̄āt) y el mundo manifestado de las formas múltiples; de manera semejante, el mundo de las Ideas-Imágenes, mundo de las formas de

41 Muhyī l-Dīn Ibn 'Arabī, Le Livore du dévoilement des effets du voyage (Kitāb al-Isfār 'an natāìğ al-asfârr), ed. bilingüe y trad. de Denis Gril, Combas: Éditions de l'Éclat, 1994, p. XIII, § 12. Trad. cast.: Ibn 'Arabī, El esplendor de los frutos del viaje, ed. de C. Varona Narvión, Madrid: Siruela, 2008, cap. 12, pp. 75-6.

42 Muhyīi l-Dīn Ibn 'Arabī, Le Livre du dévoilement des effets du voyage, o.c., p. 15, n. 45.

43 Cf. Muhȳi l-Dīn Ibn 'Arabī, L'alquimie du bonheur parfait (cap. CLXII de las Futūhāt al-makkiyya), trad. del ár. al franc. y pres. de S. Ruspoli, París: Berg International, 1981, II, 3, «Séptima morada: la divina presencia del Uno-Solo», pp. 140-1.

44 Nube primordial ( $\left.a l^{-} a m \bar{a}\right)$ producida por el Soplo del Misericordioso (nafas al-rahmān), Suspiro de Compadecimiento existenciador que permite acceder a la Presencia divina. En general, los sufies, especialmente los de la escuela de Ibn 'Arabī, consideran el cosmos como la teofanía (tağalīi) de la Verdad Divina (al-Haqq) que se renueva a cada momento. La creación es aniquilada y recreada a cada instante, lo cual en cierto sentido también es afirmado por los teólogos. La totalidad del universo pasa por el proceso continuo de expansión y contracción (al-ratq wa l-fatq). En la primera fase del proceso, el Hálito Divino o el «Hálito del Compasivo» (nafas al-rahmā $n$ ), que es la substancia fundamental del cosmos, manifiesta todas las cosas exteriorizando y dando existencia (ex-sistire) a las entidades celestiales inmutables (al-ayān al-țābita), mientras que en la segunda fase todas las cosas retornan a su Origen Divino en el que están eternamente presentes. Así pues, el cosmos depende de forma absoluta de su Fuente Divina, sin la cual literalmente no sería nada. Cf. Muhyī l-Dīn Ibn 'Arabī, Livre de la production des cercles (Kitāb inšă al-dawā ìr...), ed. bilingüe; trad. del ár., pres. y nn. de P. Fenton y M. Gloton; texto ár. establecido por H. S. Nyberg, París: Éditions de l’Éclat, 1996, pp. xxx-xxxii (de la intr.).

45 Cf. H. Corbin, La imaginación creadora en el sufismo de Ibn 'Arabī, Barcelona: Destino, 1993, pp. 217-8, 252, n. 115 , p. 384. 
aparición y de los cuerpos en estado sutil ('ālam al-mitāàl), al que se refiere nuestra facultad imaginativa (mundus imaginalis), es mediador entre el mundo de las puras realidades espirituales del universo del Misterio ('ālam al-gayb) y el mundo visible y sensible ${ }^{46}$ de la manifestación ('ālam al-šahāda); esto es, el barzah̄ī, es decir, el mundo intermedio dominado por la Imaginación activa (hayā $l$ ), la figuración sensible (mitāâl), donde las ideas y las revelaciones se convierten en imágenes sensibles, y donde lo sensible se espiritualiza. De ahí el sentido del célebre hadiz en el que un compañero del Profeta le pregunta por el situs preexistencial de «al-Rabb»: «Alguien preguntó al Profeta: ¿Dónde estaba tu Señor antes de crear su creación (visible)? -Estaba en una Nube; no había espacio ni por encima ni por debajo», queriendo decir con ello que el Nombre divino del «Señor» («al-Rabb») trasciende toda localización espacio-temporal (Latầif, 125) ${ }^{47}$. La Nube no es la completa incognoscibilidad de la Esencia (al-D̄āt), pero tampoco el mundo puro de la manifestación o Epifanía (mažhār). Es el grado (maqām) máximo al que accede la criatura, pero sin llegar al mundo de lo irrevelado, el límite del lāhūt (deidad), al conocimiento oculto del Misterio (al-gayb).

En sus Fusūṣ al-hikam (Los engarces de la sabiduría) recupera esta idea de la comprensión en la no-visión:

«La incapacidad de percibir, es ya percepción $(i d r a ̄ k)^{48}$; y entre nosotros hay quien sabe y no se expresa en esos términos, y esa es la forma más elevada de decir: de su conocimiento resulta el silencio, y no la impotencia. Este último, el callado, es el más sabio de cuantos saben con Allāh.»

46 Fut. II, 438. Trad. de M. Asín Palacios, El Islam cristianizado. Estudio del «sufismo» a través de las obras de Abenarabi de Murcia, 2. ${ }^{a}$ ed., Madrid: Hiperión, 1981 [1931], p. 480.

47 Cf. Fut. III, 429. Véase, asimismo, Fut., cap. 178. Cf. la trad. franc.: Traité de l'amour (cap. 178 de las Fut.), intr., trad. y nn. de M. Gloton, París: Albin Michel, 1986, pp. 86-8.

48 «La imposibilidad de percibir es ya una percepción (al-'ağazu 'an darak al-idrāki idrāk).» Célebre dicho de Abū Bakr que Ibn 'Arabī cita en diversas obras suyas, entre ellas en el Tarğumān al-ašwāà , referente a que la imposibilidad física de percibir lo más oculto, la divinidad, si se da con la conciencia de tal limitación, es ya por sí misma una percepción válida, indicadora de los propios límites, pero al tiempo de conciencia cierta respecto a la «realidad» del misterio. Véase también Ibn 'Arabī, El esplendor de los frutos del viaje, o.c., cap. 10, p. 72. El tanzīh nos enseña que «la vista no puede enjuiciarLo ni siquiera al contemplarLo, puesto que la mirada se encuentra en la estancia de la perplejidad (hayra) [y de la incapacidad ('aȳaz)]» (Kitāb al-ğalāl wa-l-ğamāl, ms. Berlín 2, f. 66; Rasāìl, I, p. 7). Pero, nuestra impotencia no deriva de nuestra separación respecto a Dios, sino al contrario, de estar inmersos en Él, por lo que añade que ver su Gloria es no verla, ya que «la incapacidad para percibir es la propia percepción» (ib.). Sucede como la vista humana que no puede percibir el aire ni el color del aire, o la pura transparencia, por su identidad con la percepción, ya que, «de percibirse la transparencia, la vista sería el mismo objeto contemplado (al-basar al-mubsar)» (ib.). Lo mismo sucede al contemplar un espejo, cuyas formas se perciben inmateriales y desligadas de la materia de manera similar a lo que sucede con el conocimiento sobre Dios. Pero frente a la Majestad y tanzīh de la aleya «La vista humana no Le alcanza» (Cor. 6:103), proclamando la imposibilidad de ver a Dios, la teofanía se muestra compasiva en aleyas como «Ese día, unos rostros brillarán, contemplando a su Señon» (Cor. 75:22-23), en la que Dios «desciende en su Belleza (nazala subhāna-hu fi ğamāli-hi) exponiéndose ante nosotros para que podamos percibirlo con nuestra vista» (ib., Rasā̉il, I, p. 8). 
«Las imágenes del mundo no son constreñibles ni abarcables, ni se conocen los límites de cada una de ellas, sino tan sólo lo que el conocedor es capaz de alcanzar a ver en esa imagen. Por ello mismo se desconoce el límite del Verdadero, pues Su límite no se sabe sino con el conocimiento del límite de cada imagen, y es imposible de lograr. Así, el límite del Verdadero es un hecho imposible. [...]

[...] Quien de vosotros imagine que Lo ha visto, no Le conoce; y quien de vosotros sepa que se ha visto a sí mismo, ése es el conocedor verdadero: ello es lo que divide a las gentes en sabios e ignorantes $[\ldots] .{ }^{49}$

La incapacidad de percibir, es ya percepción ${ }^{50}$... Ibn 'Arabī recupera esta unión de contrarios por medio de la visión paradójica en Mašăhid al-asrār (Las Contemplaciones de los Misterios) cuando afirma a propósito de Su trascendencia e incomparabilidad:

«Las miradas quedan cortas, los intelectos pasmados, los corazones están ciegos, los sabios están perdidos en el desierto de la perplejidad, y los entendimientos, sumidos en la estupefacción, son incapaces de aprehender el

49 Muhỵī l-Dīn Ibn 'Arabī, Fusūṣ al-hikam, ed. de A. 'Afîfi, Beirut: Dār al-Kutub al-'Arabī, 1946, II, III.

50 Moisés y san Pablo ejemplifican la imposibilidad de conocer a Dios; el primero, cuando penetró en las tinieblas de la inaccesibilidad y, el segundo, cuando oyó las palabras que expresaban la inefabilidad divina. El rostro cubierto de Moisés nos habla de una visualidad que se dirigiría hacia lo invisible por excelencia, Dios inefable y sin imagen, hacia la «eminencia impensable» entre Dios y el hombre, su distancia insalvable. Este Dios impensable es el Absconditum, cuya incognoscibilidad comporta el fundamento abismal del alma, y que queda simbolizada en el pasaje bíblico de Moisés ante la zarza ardiente (las tinieblas de la inaccesibilidad), tal como lo desarrolla Gregorio de Nisa en su Vida de Moisés. También en el conocido episodio de san Pablo y su visión-ceguera en el camino de Damasco («con los ojos abiertos nada veía», Hch 9:8): palabras de la inefabilidad divina. Maestro Eckhart afirma que Pablo «ve la Nada (de Dios)»-unt daz nicht was gott (Pr. 71). También en el texto «apócrifo» de los Hechos de Pedro hallamos un relato que ilustra de manera ejemplar un caso de visión teofánica, texto que conserva las huellas de la espiritualidad gnóstica y su docetismo. Dicho relato ejemplifica las metamorfosis de las visiones teofánicas. En él el apóstol Pedro evoca, ante una asamblea, el acontecimiento de la Transfiguración acaecida en el monte Tabor. De aquel acontecimiento que no fue visible más que a algunos y no para los ojos del cuerpo, no puede decir más que una cosa: Talem eum vidi qualem capere potui. «Lo he visto tal como estaba en condiciones de percibirlo». El apóstol se apremia a decir: «Percibid en el interior de vosotros mismos, en vuestro espíritu, lo que no podéis ver con vuestros ojos». Habiéndose puesto la asamblea en oración, todo se ve envuelto por una luz deslumbrante, no semejante a la luz del día, sino inefable, invisible, indescriptible. Y la resplandeciente luz entra en los ojos de las viudas que estaban ciegas y que ahora creen, y esta luz que hace ver, las hace videntes. Se les pregunta lo que han visto: algunas han visto un niño, otras un adolescente, otras un viejo... (Cf. HchPe, caps. XX-XXI. M. Rhodes James, The Apocryphal New Testament: being the Apocryphal Gospels, Acts, Epistles, and Apocalypses, with other narratives and fragments, Oxford: Clarendon Press, 1950, pp. 321-3). Cada uno ha visto de forma diferente y apropiada según la capacidad de su ser. Cada uno puede decir: talem eum vidi qualem capere potui. Esta percepción es esencialmente un acontecimiento del alma, que tiene lugar en el alma y que acontece para el alma. Lo que ve realmente un alma no es visible más que para ella sola; y las almas se distinguen entre ellas precisamente por su modo y su capacidad de percepción. 
más ínfimo secreto de la epifanía de Mi Grandiosidad. ¿Cómo, entonces, podrían abarcarla? Vuestra ciencia es polvo diseminado. Vuestros atributos no son nada. Vuestra realidad es sólo una metáfora en un remoto rincón de Mi existencia.

Vuelve atrás, pues no podrás rebasar [los límites que impone] tu rango. Tú, como cada uno de vosotros, Me desconoces, eres incapaz e insuficiente, estás mudo, ciego, sin habla y perplejo, y no tienes absolutamente nada, por pequeño que sea, que te pertenezca.» ${ }^{51}$

Este gnóstico, por cuyo corazón discurren cada día setenta mil secretos de la divina Majestad que jamás retornan a él, es al mismo tiempo respecto a Dios, como el resto de sus congéneres, ignorante, mudo, ciego e incapaz ${ }^{52}$. Las palabras «ignorante, mudo, ciego e incapaz» aluden al más alto grado de comunión con la existencia (en donde coinciden ignorancia y sabiduría, afirmación y negación, manifestación y ocultación), que le es posible, desde la perspectiva akbarí, alcanzar al ser humano. Este «gnóstico» es ignorante porque no puede esgrimir ninguna definición concluyente acerca de la naturaleza última de la realidad (dado que esta es unión de contrarios); carece de habla porque queda mudo ante la imposibilidad de expresar lo inefable; es incapaz porque, al comprender que el verdadero poder de la existencia no reside en él, se desprende de cualquier vestigio de voluntad propia; y es ciego, en suma, puesto que Dios se ha convertido en su vista, su oído y en todas sus facultades de percepción y entendimiento, de acuerdo con el hadīt o tradición profética que declara: «Mi servidor se acerca continuamente a Mí a través de las obras meritorias hasta que Yo le amo y cuando Yo le amo, Yo soy el oído a través del cual oye, Yo soy la vista a través de la cual percibe, soy la lengua con la que habla, soy la mano con la que atrapa y soy el pie con el que camina».

Este es el punto de partida para tratar el tema que nos ocupa: la imagen de la no-imagen y el desapego místico de las imágenes ${ }^{53}$.

51 Muhỵī l-Dīn Ibn 'Arabī, Las Contemplaciones de los Santos Misterios y las Ascensiones de las Luces Divinas (Mašăhid al-asrār al-qudsiyya wa-matāli‘ al-anwār al-ilāhiyya), intr., ed., trad. del ár. y nn. de S. Hakim y P. Beneito, Murcia: Editora Regional de Murcia, 1994, cap. VI, p. 66.

52 Ib., p. XV de la intr.

53 Para un análisis de la imagen más allá de la imagen o de la no-imagen véanse V. M. Fóti, Vision’s Invisibles. Philosophical Explorations, Albany: State University of New York Press, 2003, índice s.v. «image», «invisible(s)»; M. Gerhart, «The World Image Opposition: The Apophatic-Cataphatic and the Iconic-Aniconic Tensions in Spirituality», o.c., pp. 63-79; A. Gonzalo Carbó, «El arte abstracto y lo indecible: el fondo abisal de la obra de arte», Convivium. Revista de Filosofia, n. ${ }^{\circ} 11$ (1998), pp. 128-151; id., "Ojos aniquilados: ceguera reveladora y apagamiento de las imágenes en el cine de Angelopoulos, Bresson, Kiarostami, Majidi, Sokurov», Convivium. Revista de Filosofia, n. 22 (2009), pp. 195-218; id., «El ver que excede la vista en Maurice Merleau-Ponty y Jean-Luc Godard», Convivium. Revista de Filosofia, n. ${ }^{\circ} 24$ (2011), pp. 139-62; id., «El desierto de la no-imagen y las ruinas de la annihilatio en el cine de Kiarostami, Mehrjui y Raisian», Mundo Iranio, n. ${ }^{\circ} 0$ (enero 2012), pp. 23-32; M. Henry, Ver lo invisible. Acerca de Kandinsky, Madrid: Siruela, 2008; T. Izutsu, «Between Image and No-Image: Far 
Para muchos poetas contemporáneos -Bonnefoy, Valente, Colinas, Gamoneda- lo blanco o la blancura, en la línea trazada por Mallarmé, es la terra incognita de lo «indecidible» (Derrida, a partir de Mallarmé), allí donde se cumple la «abolición» de sí (Mallarmé) o la «autodisolución» o «autoabolición» (Valente). Blancura abisal originaria: del «abismo blanco» de Mallarmé al «espacio en blanco» de Jacques Derrida. El pensador francés interpreta que la ausencia de la cópula verbal -el espacio en blanco, el breve hiato de la pausa oral- no sólo contiene la virtualidad lingüística por excelencia, la depurada forma del Silencio, sino también la representación máxima del ser ausente ${ }^{54}$, «el ser desnudo sin forma (das blose formlose wesen) de la unidad divina ${ }^{55}$. Según Ibn 'Arabī, la fase más elevada de la perfección humana exige que los nombres divinos alcancen un equilibrio tal que los seres humanos sean incoloros y no delimitados por nombre alguno, como el propio wuğūd (el Uno «sin color» en la poética de $\left.\operatorname{Rūmin}^{-56}\right)$. Ésta es la estación de la no-estación (maqūm lā maqām), en la que ninguna cualidad

Eastern Ways of Thinking», en A. Portmann; R. Ritsema (eds.), Denken und Mythische Bildwelt [Eranos-Fahrbuch, n. ${ }^{\circ} 8$ (1979)], Fráncfort d. M.: Insel Verlag, 1981, pp. 427-61 [«entre la imagen y la no-imagen» o «de la noimagen a la imagen» en el I Ching, el taoísmo clásico de Lao Tzǔ - Chuang Tzǔ, y la Nada en el buddhismo Zen]; M. Jay, Ojos abatidos. La denigración de la visión en el pensamiento francés del siglo XX, Madrid: Akal, 2008; F. Jullien, La gran imagen no tiene forma, o, del no-objeto por la pintura. Ensayo de des-ontología, Barcelona: Alpha Decay, 2008; B. Lane, «Sinai and Tabor: Apophatic and Kataphatic Symbols in Tension», o.c., p. 189; B. Latour; P. Weibel (eds.), Iconoclash: Beyond the Image Wars in Science, Religion, and Art, cat. exp. ZKM/Center for Art and Media, Karlsruhe, Cambridge; Londres: The MIT Press, 2002; M. Merleau-Ponty, El ojo y el espiritu, Buenos Aires: Paidós, 1977; G. Scholem, Von der mystischen Gestalt der Gottheit. Studien zu Grundbegriffen der Kabbala, Zúrich: Rhein-Verlag, 1962, p. 34 [trad. ingl.: On the Mystical Shape of the Godhead. Basic Concepts in the Kabbalah, Nueva York: Schocken Books, 1991, pp. 41-2]; C. Stewart, «Imageless Prayer and the Theological Vision of Evagrius Ponticus», Fournal of the Early Christian Studies, n. ${ }^{\circ}$ 9:2 (2001), pp. 173-204; M. C. Taylor, «Think Naught», en R. P. Scharlemann (ed.), Negation and Theology, Charlottesville; Londres: University Press of Virginia, 1992, pp. 25-38, 27 (sobre la pintura de Ad Reinhardt); J.-P. Sylvestre (dir.), Montrer l'invisible. Figuration et invention du réel dans la peinture, Dijon: Éditions Universitaires de Dijon, 1994; K. Tanner, «In the Image of the Invisible», en Ch. Boesel; C. Keller (eds.), Apophatic Bodies. Negative Theology, Incarnation, and Relationality, Nueva York: Fordham University Press, 2010, pp. 117-136; D. Turner, The Darkness of God. Negativity in Christian Mysticism, Cambridge: Cambridge University Press, 1995, cap. 7, pp. 168-85; índice s.v. «apophaticism»; W. Wackernagel, Ymagine denudari. Étique de l'image et métaphysique de l'abstraction chez Maître Eckhart, París: Librairie Philosophique J. Vrin, 1991, cap. 10: «Vers un au-delà de l'image», pp. 146-64; id., «L'être des images», en E. Zum Brunn (comp.), Voici Maître Eckhart, Grenoble: Jérôme Million, 1994, pp. 455-72.

54 «Ocurre así que la ausencia léxica [en la frase nominal] puede no ser "suplida" más que por una ausencia nada más, siendo garantizada entonces la función gramatical de "ser" por el blanco de un espacio, por una puntuación de algún modo borrada, por una pausa: interrupción oral, es decir, una parada de la voz (¿es entonces un fenómeno oral?), que ningún signo gráfico, en el sentido ordinario de esta palabra, que ninguna escritura plena viene a señalar. La ausencia de "ser", la ausencia de este lexema singular, es la ausencia misma.» J. Derrida, «El suplemento de la cópula. La filosofía ante la lingüística», en Márgenes de la filosofía, Madrid: Cátedra, 1989, p. 241.

55 J. Derrida, «Cómo no hablar. Denegaciones» (1986), en Cómo no hablar y otros textos, 2. ${ }^{a}$ ed., Barcelona: Proyecto A, 1997 [1989], p. 50.

56 Una de las formas simbólicas que Ğalāl al-Dīn Rūmī emplea con más frecuencia para referirse a lo que Hegel denomina el abandono del mundo «empírico y mundano» en búsqueda de «la unidad del alma con el Uno», es la expresión «más allá de los colores y perfumes de este mundo». El paso del mundo de los colores, el 
específica se sobrepone a las otras ${ }^{57}$. Si las personas se desarrollan en armonía con el wuğūd no delimitado e incoloro, alcanzarán una estación que, más que conocida, cabe considerar desconocida, la «estación de ninguna estación».

Según al-Šayh al-Akbar, la realidad divina, tal como es en sí misma, resulta demasiado excelsa para que pueda contemplarla ojo limitado alguno, pues sólo Dios ve a Dios. Las teofanías más allá de la forma, que revelan la esencia divina en su completa desnudez ${ }^{58}$, exigen la aniquilación del sujeto que, en el meollo de la experiencia, ignora incluso que está viendo a Dios. Sólo puede aprehender ese portentoso hecho una voz que retorna a su conciencia ordinaria. Así, en uno de sus escritos, refiere Ibn 'Arabī: «El que me ve y sabe que me ve, no me ve.» ${ }^{59} \mathrm{El}$ conocimiento supremo de Dios coincide, de manera tan chocante como ineludible, con la ignorancia absoluta del propio yo, estando reservado para quien, sumido en la noche de su nada original, ha olvidado incluso su propio ser ${ }^{60}$.

Hay un elemento que se interpone entre el sujeto que contempla y lo por él contemplado que, de forma paradójica, potencia la visión: la nube opaca, mediadora entre la Esencia divina abscóndita (al- $\underline{-} \bar{a} t)$ y el mundo manifestado de las formas múltiples y que constituye el velo teofánico supremo (Ibn 'Arabī), el cerro y el seto que impiden ver el último horizonte (Giacomo Leopardi, «El infinito»), la bruma que evapora la percepción del paisaje (Claude Monet, Andrei Tarkovski, Theo Angelopoulos), la niebla de la auto-evaporación o autoinmolación (El destino de la señora Yuki, Kenji Mizoguchi), el humo de la pira en el que se extinguen los cuerpos de forma imperceptible (secuencias finales de $L a$ pasión de Juan de Arco, C. Th. Dreyer; El proceso de Juana de Arco, Robert Bresson) o el humo blanco del volcán en erupción como manifestación velada de lo sagrado (Stromboli, Roberto Rossellini), la luna ensombrecida por las nubes como presagio de la auto-aniquilación (Mouchette, Robert Bresson; El sa-

mundo sensible, al mundo más allá de los colores o incoloro, el mundo inteligible, es la bella expresión simbólica que el místico de Rūm utiliza en el itinerarium in Deum para designar la llegada al universo de la Unidad. El mundo de la Unidad divina es un «océano sin orillas», mientras el mundo de la multiplicidad es un «mundo hecho de agua y de arcilla». Se trata del Uno inefable que, según Rūmī, «no tiene color» ( $b \bar{\imath}$ rang $\vec{\imath}$ ), o bien, según los

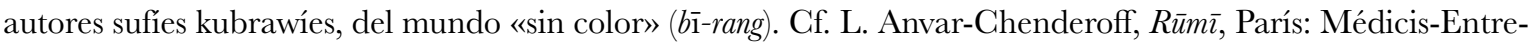
lacs, 2004, pp. 191-2; E. Meyerovitch, Mystique et poésie en Islam. Djalâl-ud-Dīn Rūmī et l'ordre des derviches tourneurs, París: Desclée de Brouwer, 1972, pp. 157-62.

57 Cf. W. C. Chittick, Mundos imaginales: Ibn al-'Arabīy la diversidad de las creencias, Madrid: Mandala, 2003, pp. 84-5, 110-3, 283; id., The Sufi Path of Knowledge. Ibn al-Arabì's Metaphysics of Imagination, Albany: State University of New York Press, 1989, pp. 375-9.

58 Para estas teofanías más allá de la forma o de las imágenes véanse M. Chodkiewicz, «The vision of God according to Ibn Arabi», en S. Hirtenstein (ed.), Prayer and Contemplation, Fournal of the Muhyiddin ibn Arabi Society (1993), pp. 53-67 [en franc.: «La vision de Dieu selon Ibn ‘Arabī», en É. Chaumont (et al.) (eds.), Autour du regard. Mélanges Gimaret, Lovaina: Peeters, 2003, pp. 159-72, en concreto p. 167; C. Addas, Ibn Arabī et le voyage sans retour, París: Éditions du Seuil, 1996, «La vision suprême», pp. 60-3; F. Mora, Ibn 'Arabĩ. Vida y enseñanzas del gran maestro andalusí, Barcelona: Kairós, 2011 , cap. 7: «"Luz sobre luz”: más allá de las imágenes», pp. 229-41.

59 Fut. IV, p. 125. Cit. C. Addas, ib., p. 62.

$60 \mathrm{Ib}$. 
$\vdots$

bor de las cerezas, Abbas Kiarostami), el propio «negro velo de la mirada» (Paul Celan), el ojo cegador (Lezama Lima), el parche en el ojo que agudiza el otro ojo (Fritz Lang, John Ford, Nicholas Ray), las gafas no prescritas que el pintor lleva puestas durante años para desarrollar la visión interior (Bram van Velde), la ceguera terminal de la enfermedad del sida y la inmersión en el azul inefable (Blue, Derek Jarman)...

Por medio del uso recurrente en el cine de Godard al fundido en negro o la pantalla negra (como en el de Bresson, Garrel, Hou Hsiao-hsien, Kiarostami), la luz que se apaga, la imagen se ensombrece ante lo que no puede ser mostrado, pero la oscuridad, en vez de suponer una limitación, alumbra lo invisible. La luz es entonces verdaderamente negra ${ }^{61}$.

«Cegado con negro, quemado con blanco, vuelto opaco con gris, es el vínculo entre el hombre y el mundo el que deja de ser evidente. Y ello puede llegar hasta el caso de la pantalla toda negra o toda blanca, punto límite de la expresión de lo irrepresentable, punto final de la representación: véase en particular en Duras o Garrel (caso, entre muchos otros, que no ignoran Bergman o Fassbinder).

De ello es testimonio el status de la blancura en la modernidad, desde Rossellini hasta Bresson, desde Pasolini hasta Antonioni, desde Wenders hasta Garrel, o también en Godard: silencio de Dios (al menos en los tres primeros), apertura o blanco de la representación, conciencia interpelada y cegada, plano ofrecido en holocausto ${ }^{62} .{ }^{63}$

El cine ha sabido, sobre todo por medio de la luz, aludir (metafórica, simbólicamente) al misterio último que pervive latente, oculto, en este mundo. Pero más que a la no manifestación, a la abscondidad en sí del Principio, más bien el arte del cinematógrafo ha pretendido plasmar las dificultades y aporías de mostrar lo irrepresentable, de expresar lo indecible, y, no obstante, a pesar de su inevidencia, pre-

61 Cf. G. Agamben, «Du noir», en A. Meddeb (dir.), Le paradoxe des représentations du divin. L'image et l'invisible, Dédale, n. ${ }^{\circ}$ 1-2 (otoño 1995), París: Maisonneuve et Larose, pp. 111-3; H. Corbin, El hombre de luz en el sufismo iranio, Madrid: Siruela, 2000, cap. V: «Luz negra», pp. 113-32; T. Izutsu, «The Paradox of Light and Darkness in the Garden of Mystery of Shabastarì», en J. P. Strelka (ed.), Anagogic Qualities of Literature, University Park; Londres: The Pennsylvania State University Press, 1971, pp. 288-307; M. J. Mancho Duque, El símbolo de la noche en San Fuan de la Cruz. Estudio léxico-semántico, Salamanca: Universidad de Salamanca, 1982; D. Repetto, Teología y santidad: un retorno a la unidad: ensayo interdisciplinar a partir del símbolo de la Noche en fuan de la Cruz, Buenos Aires: Guadalupe, 2006; A. Sánchez Robayna, La luz negra (ensayos y notas, 1974-1984), Madrid: Júcar, 1985; J. Tanizaki, El elogio de la sombra, Madrid: Siruela, 1995.

62 Silencio de Dios: como en Los comulgantes de Bergman, donde sin embargo la blancura está instaurada (por el decorado) y cultivada, y con ella ese sentido metafórico. Una película límite: en el fondo, modernidad, en la forma, clasicismo esquematizado.

63 F. Revault d'Allonnes, La luz en el cine, Madrid: Cátedra, 2003, p. 93, pp. 92-3. 
sencia ausente o ausencia presente, de esta inanidad ontológica o supraontológica, poder finalmente desgarrar fragmentos de visibilidad de la materia oscura invisible:

«El misterio (también lumínico) del mundo: eso es lo que plasman y persiguen los modernos, desde Rossellini hasta Bresson, desde Antonioni hasta Pasolini, desde Godard hasta Garrel. El final de Stromboli o de Alemania, año cero, El diario de un cura de campaña, La aventura o Accattone, El soldadito, Liberté, la nuit (por no citar más que éstas): si la luz es espíritu, es una espiritualidad inmanente en el mundo, que permanece latente, difusamente grabada en él, como una filigrana. [...] Esta blancura insondable, este gris impenetrable, si son la huella de Dios (o del espíritu, en definitiva, del vínculo, del sentido), son el eco de su silencio o inevidencia. Si hay metáfora, está documentalizada, es plana, se basa en la naturaleza; es la de un desgarramiento, de una mancha ciega.

[...] El lenguaje está sin duda todavía al servicio de una inevidencia primordial del mundo, que expresa. La magia cinematográfica sin duda sigue al servicio del misterio ontológico, que prolonga.» ${ }^{64}$

Nuestra exposición versa pues sobre la des-ontología, la teología negativa, el lenguaje místico que «abre el vacío de un innombrable» y el correspondiente desapego místico de las imágenes -tanto en el contexto de las tradiciones espirituales orientales (Lao zi, Farīd al-Dīn 'Aț̣ār, Ibn 'Arabī) como occidentales (Maestro Eckhart, Enrique Suso)- y su trasposición tanto a las diversas formas neoteóricas de misticismo en la lírica moderna y contemporánea (Stéphane Mallarmé, Rainer Maria Rilke, Paul Celan, Octavio Paz, Edmond Jabès, Yves Bonnefoy, José Ángel Valente, Antonio Gamoneda, Bernard Noël, Jacques Ancet, Antonio Colinas), como, asimismo, al soporte cinematográfico (Carl Theodor Dreyer, Robert Bresson, Andrei Tarkovski, Marguerite Duras, Jean-Luc Godard, Philippe Garrel, Abbas Kiarostami). La mística: una abertura sobre la indefinida probabilidad del otro. «El otro -afirma Jacques Lacan- está ahí... en la medida justamente en que es reconocido pero no conocido.» ${ }^{65}$ «Ese Otro que yo llamo el Dios oscuro.» ${ }^{66}$

De estos escritores, se sabe que Mallarmé se interesó vivamente por la literatura ocultista, y, probablemente, por la teología negativa, y que esta última está presente de forma velada en la poesía de Rilke y claramente explícita en la obra de Celan, Jabès, Bonnefoy o Valente. El recurso común a estos poetas y cineastas es la imagen simbólica de la blancura insondable, que podría ser la traducción al campo de la escritura lírica y del cine poético de la luz increada de las diversas tradiciones espirituales.

64 Ib., pp. 144-5.

65 J. Lacan, Séminaire III. Les Psychoses, París: Seuil, 1981, p. 48.

66 J. Lacan, Les Quatre Concepts fondamentaux de la psychanalyse, París: Seuil, 1973, p. 247. 
En su Kitāb al-Tă̌alliyāt al-ilāhiyya (El Libro de las teofanías) Ibn 'Arabī desarrolla su concepción de la antropología mística. En esta obra entrecruza dos temas que se sitúan en el corazón mismo de la doctrina akbarí: el del tawhìd (el secreto del Uno sin segundo, afirmación o reconocimiento de la Unicidad divina, fundamento del credo musulmán; realización interior de esta doctrina en el sufismo) y el de las teofanías que fundamentan la multiplicidad de los existentes sin comprometer la unicidad del Ser, puesto que no son más que manifestaciones de Él mismo a Él mismo. Texto alusivo y paradójico, tal tratado ofrece la particularidad de presentarse en muchas ocasiones bajo forma de diálogos entre alŠayh al-Akbar y grandes sufies del pasado: Ǧunayd, Sahl al-Tustarī, Hallāğ, D̄ū l-Nūn el Egipcio... En las teofanías n. ${ }^{\circ}$ 70-73, Ibn 'Arabī nos presenta un escenario abreviado de ascensión mística hacia la Divinidad que se devela bajo los atributos de la «Luz muhammadí» cuyos tres colores (rojo, blanco y verde) son los indicios epifánicos, y en compañía, respectivamente, de 'Alī b. Abī Ṭālib (m. 40/661), el cuarto califa, de Abū Bakr al-Șiddīq (m. 13/634), el primer califa y uno de los más allegados al Profeta, y de 'Umar b. al-Hुattāb (m. 23/644), el segundo califa. El Šayh̆ reserva a los Compañeros del Profeta las claves del tawhì d esotérico que reposan en la armonía de los complementarios, y les atribuye naturalmente las estaciones superiores de la walāya de elección que limitan con el conocimiento profético, simbolizado por estas teofanías luminosas. Así, esta tríada que se orienta hacia la «luz de lo invisible» (T. 75) anuncia mejor la «teofanía de la gloria» (T. 77) de la que es el fundamento doctrinal. Las tres teofanías de colores forman la coalescencia de la «Luz muhammadí» en calidad de primera determinación metafísica de Luz pura que es incalificable y por consiguiente sin color. En el contexto de esta ascensión, se trata de la luz suprema del invisible (T. 75).

Se puede resumir en función de los comentarios el simbolismo de estos tres colores de la manera siguiente. Se trata de las modificaciones epifánicas de un sola y única luz, es decir, de las determinaciones de lo absoluto. O también: estos colores son los velos teofánicos superiores de la Luz divina que es puramente suprasensible o invisible. Desde el punto de vista cosmológico, constituye la siguiente progresión: la luz roja indica el paso del malakūt inferior (mundo celeste); la luz blanca, el límite del malaküt superior; la luz verde, el umbral del ğabarūt (mundo inteligible); mientras que la «luz de lo invisible», que ningún color permite comprender, coincide con el lāhūt (mundo suprasensible puro), o esfera de la Esencia divina indeterminada. En relación con esta distribución, la ascensión del peregrino se descompone en dos fases: la primera hacia Dios, a través de las tres teofanías de colores que delimitan el malakūt y el ğabarūt, y la segunda en Dios [T. 73]. Las variaciones de los colores rojo, blanco y verde que afectan a los ojos del peregrino en su conocimiento del ser absoluto le hacen comprender que Dios es precisamente incognoscible en su esencia, pero únicamente cuando él se califica por los fotismos de la Luz muhammadí.

Estamos aquí más cerca del misterio de la Esencia que simboliza «la luz resplandeciente» (al-nūr al$\check{s} a(\breve{s} a(\bar{a} n \bar{i})$ «por medio de la cual se percibe pero que ella misma no puede ser percibida» debido a su resplandor cegador. La luz roja, precisa el Kašf al-gāāàt, un comentario anónimo, no es más que la reflexión de esta luz de la Esencia en la inmensidad del jayāl mutlaq, y no se trata pues aquí sino de 
una ru’ya mitāliyya, de una visión en modo imaginal. La luz blanca representa un grado más elevado que las luces roja y verde pues - tal como el propio Ibn 'Arabī le dice a Ibn Sawdakīn- «el color blanco es el único que acoge todos los otros... Su rango es el del Nombre de Majestad [Allā $h]$ entre los otros Nombres y el de la Esencia entre los atributos». La superioridad del blanco sobre el resto de colores se respeta, no anteponiéndolo a la primera posición, sino manteniendo la virtud de ocupar una posición intermedia (barzaj). Pero Abū Bakr, que permanece en esta luz blanca, tiene no obstante la mirada vuelta hacia Occidente - el lugar de ocultación de la luz- pues Occidente es «la mina de los secretos»: así se nos dice claramente que es más allá de las teofanías formales más elevadas, más allá de las luces creadas, donde se revela, a aquél que se vuelve hacia la tiniebla «occidental», la luz increada de la Esencia divina.

Por último, en esta escala de ascensión cromática, después de haber alcanzado el tawhìd de la abolición [T. 74], el místico se halla en la estación de la teofanía de la «luz de lo invisible» (nūr al-gayb), donde ve y conversa con el gran maestro espiritual y teólogo Md. Sahl b. 'Abdullāh al-Tustarī (m. 283/896) [T. 75]. Esta luz es la luz divina no-condicionada, la que procede del absconditum divino (gayb), que los pensadores ismāîíies y las escuelas del sufismo de Asia central (kubrawíes y naqšbandíes) llaman el «Misterio de los misterios». Se trata de la luz pura de lo Absoluto, y por ello incolora. La «luz de lo invisible» se refiere al ser absoluto que trasciende toda determinación, el Dios cuya esencia es incognoscible (al-gayb). En la cosmología de Ibn 'Arabī es el «Tesoro oculto», la esencia incognoscible, que trasciende toda determinación y calificación. Corresponde a la idea de la «luz negra» en la obra de Šams al-Dīn Lāhīḡì y Nağm al-Dīn Rāzī, llamada igualmente «luz de luces», luz sin color, etc. Como la mayor parte de los metafísicos musulmanes, el autor de las Futūhāt ha profundizado en la tipología coránica de los términos gayb y šahāda, que designan respectivamente el plano de la pura esencia y el plano de la manifestación visible, que sólo Dios conoce en su realidad intrínseca (véase Fut. III, 78). En otras obras (por ejemplo en El Libro de las contemplaciones divinas, cap. 2), Ibn 'Arabī recurre directamente al simbolismo de la tiniebla divina para designar el absconditum. Esta concepción se une a la de la «tiniebla luminosa» (supraluminosa) de la obra de Dionisio Areopagita, retomada por toda la tradición patrística cristiana.

Esta teofanía pone de relieve pues el tawhìd esencial, y marca el punto culminante de la progresión a través de los trechos de la walāya muhammadí tipificada por los colores rojo, blanco y verde que Ibn 'Arabī ha atravesado en su ascensión mística. (T. 70-73). Finalmente, el místico se introduce en el misterio de la Luz que es invisible en sí, puesto que es la de Dios mismo, pero por medio de la cual todo se puede very conocer. El peregrino experimenta así el paradójico conocimiento de lo impenetrable: la esencia inefable de Dios. Pues si Dios se vuelve accesible en forma de luz, siendo Él mismo la fuente de la luz, no puede ser aprehendido más que por la via negationis. Esta es la razón por la cual la progresión del peregrino a través de estas teofanías de colores que señalan el umbral límite de la visión desemboca en la luz apofática de lo invisible. En las estaciones superiores del tawhīd, en presencia de la Divinidad inefable, el intelecto ya no puede discurrir, pues en el umbral de lo invisible ya no hay nada por decir ni describir. 
Por ello, al final de esta ascensión espiritual (T. 75), el Šayh da entender a Sahl al-Tustarī que cuando se llega a la estación de la luz apofática la única respuesta posible es «el silencio».

Seguramente, la «blancheur d'abîme» («abismal blancura», Principio y fin de la nieve, poemario de Yves Bonnefoy) a partir del «l'Âbime / blanchi» («el abismo se blanquea», Una tirada de dados, Mallarmé) sea la expresión, en el contexto secular contemporáneo, de la «luz de lo invisible» de la que nos habla Ibn 'Arabī en El Libro de las teofanías, la luz apofática del absconditum divino (gayb) que trasciende toda determinación y atributo, o de la teología mística sobre la luz tabórica elaborada, en el contexto de la tradición bizantina, por Gregorio Palamas, o bien de la Luz Clara (tib. 'od-gsal, pr. ösel) y sin color del buddhismo tibetano o de la luz suprema de la vacuidad (shūnyatā), la realidad no articulada, en el buddhismo Mahāyāna.

Hay un blanco sepulcral vinculado a la muerte, blanco sobre blanco, que se repite en la tradición literaria occidental, blanco revenant: las gotas de sangre sobre la nieve que contempla Perceval (Cuento del grial, Chrétien de Troyes), «página en blanco» o «blanca agonía», «abismos deslumbrados» (Mallarmé), «lecho de nieve», «blancura invisible» (Paul Celan), «el blanco que está en el fondo de lo que no tiene fondo» (Maurice Blanchot), «éxtasis blanco», «muerte deslumbrada» (Michel de Certeau), «la blancura en su ser abismal» (María Zambrano), extinción de sí y absorción en la vacuidad del blanco (Bonnefoy, Valente, Gamoneda), que es la escritura en forma de borradura para figurar al Otro («abolición» que constituye una «aurora», Herodías)... La muerte - para el también poeta Edmond Jabès- es el umbral, el espacio en blanco, entre dejar de ser y comenzar a ser. Así pues, el silencio es el umbral de la palabra y la página en blanco el umbral del libro. En la escritura de Celan, Blanchot y Jabès el desierto es blanco. El poeta Yves Bonnefoy, en Principio y fin de la nieve, hace referencia a la «blancheur d'abîme» («blancura abismal») de las páginas del libro sobre las cuales sólo hay «signos indescifrables». Estas páginas blancas, espacio virgen, constituyen, como en Mallarmé, una Nada auto-referencial: «Je recherche surtout, dans la blancheur» («Busco sobre todo, en la blancura»).

Fulguraciones visionarias aniquilantes, deshacimiento en la luz que ilumina anonadando. «Y ahora -añade María Zambrano-, ya conocía aquel desierto, aquella blancura sin fronteras. ${ }^{67}$ La blancura deslumbrada, el blanco sobre blanco, la nieve acumulada, es para los místicos de la aniquilación -Ibn 'Arabī, Rūmī'-, para los escritores de la autodisolución -Wang Wei, Bashō, Mallarmé, Celan, Jabès, Blanchot, Valente, Gamoneda-, para los cineastas de las imágenes en extinción -Dreyer, Bresson, Bergman, Duras, Garrel, Kiarostami- el espacio desértico del vacío esencial y la disolución última:

«En la cerámica china, el blanco - color de fondo, y no se olvide que el blanco es un no-color (blanco-gris-negro: azul-amarillo-rojo)- aísla lo representado reduciéndolo a su soledad esencial. Las figuras (loto, almen-

67 M. Zambrano, Delirio y destino. Los veinte años de una española, en M. Zambrano, Obras completas VI, coord. y rev. de J. Moreno Sanz, Barcelona: Galaxia Gutenberg; Círculo de Lectores, 2014, p. 852. 
dro, hombre en meditación) existen sobre el blanco, es decir, sobre el vacío esencial. El silencio cumple en lo poético igual función. Así aparece en mi "Cerámica con figura sobre fondo" (del libro Interior con figuras, 1976). Y sobre el silencio la palabra poética no es comunicación sino aparición.» ${ }^{68}$

«He aquí una escuela duradera que también nosotros hemos - a nuestro modo- de seguir, porque resumimos una muy remota tradición, según la cual la Tora está escrita en los espacios blancos que separa una letra de otra. Escritura invisible o intersticial. Lo blanco. Cerámicas con figuras sobre fondo blanco. Conocer lo blanco es llegar al no-conocimiento, porque en lo blanco todos los colores se disuelven y todas las oposiciones quedan abolidas. Sentarse y olvidar. Así - explica Kristofer Schipper- empieza a practicarse, según la sabiduría taoísta, el ayuno del corazón. Y quizá también empezaríamos a responder de ese modo a la cuestión poética que todavía nos aflige: ¿cómo combinar palabra y silencio sin alterar la realidad? Técnica de autodisolución o de autoabolición, la escritura.» ${ }^{69}$

Lo mismo se puede decir de la imagen cinematográfica - el blanco sobre blanco (Dreyer, Bresson), la explosión de luz blanca con que concluye El eclipse (Michelangelo Antonioni), «la blancura blanca» (Aurélia Steiner [Vancouver], 1978, Marguerite Duras), el paisaje níveo o boreal de lo absoluto (Tarkovski), la página en blanco de Mallarmé llevada a la pantalla del cinematógrafo (Guión del filme «Passion», 1982, Jean-Luc Godard), la sobreexposición de la imagen (Philippe Garrel), las imágenes borrosas o el fundido en blanco (Abbas Kiarostami)- como expresión de las antiguas teofanías más allá de las formas o de la imágenes: en definitiva, la imagen de la no-imagen. Es el «blanco sobre blanco imposible de filmar» (Dreyer), o también el «construye tu película sobre lo blanco» (Robert Bresson), que, en el primer caso, según palabras de André Bazin, constituye «una metafísica del blanco».

La pantalla vacía de imágenes es considerada por André Bazin no como un vacío, sino como un logro y un triunfo. Bazin analiza una de las películas que utilizan de forma muy expresiva este recurso: Diario de un cura rural (1950), de Robert Bresson, en la que la relación entre imagen y texto lleva al uso de la pantalla vacía. Llega un momento del filme en el que la imagen desaparece. Bazin describe este caso en el que la imagen se retira de la pantalla como una evidencia del «cine puro»: «En el punto al que Bresson ha llegado, la imagen sólo puede decir algo más desapareciendo. El espectador ha sido progresivamente conducido a esta noche de los sentidos cuya única expresión posible es la luz sobre la pantalla blanca. [...] Pero experimentamos con evidencia estética irrecusable un logro sublime del cine puro. Como la página en blanco de Mallarmé o el silencio de Rimbaud es un estado supremo del lenguaje, la pantalla vacía de imágenes $[\ldots] »^{70}$.

68 J. Á. Valente, «El silencio», en Obras completas II. Ensayos, o.c., p. 1285.

69 J. Á. Valente, «El sueño de Daniel», ib., pp. 1458-9. (La cursiva es nuestra).

70 A. Bazin, ¿Qué es el cine?, Madrid: Rialp, 1990, p. 146. 
Como expresión en el campo del arte de las teofanías sin formas y la imagen-sin-imagen secreta allende las imágenes se puede hacer referencia a la obra cinematográfica del realizador iraní Abbas Kiarostami, en concreto a las tomas tres y cinco de la playa sobrexpuesta a la luz y del plano nocturno del agua en la oscuridad de la tormenta subexpuesta a la luz de Five. Dedicated to Ozu (2003). Se trata de los dos polos que expresan por igual la Luz pura que es incalificable. La película se compone de cinco largas tomas, intercaladas por fundidos a blanco o negro. Detrás de la aparente estática de estas cinco tomas que conforman Fïve se esconde mucho más que esto, pero requiere un ejercicio exhaustivo de contemplación por parte del espectador, que debe dejarse llevar por la película. Como Kiarostami cree más en la vida que en las imágenes, parte siempre de ella y despoja la imagen de todo lo que pueda interferir su curso. El cineasta iraní valora sobre todo el contacto directo con la realidad que la cámara tiene delante; por eso, busca intensificar esa experiencia vital. Esa actitud comienza por una observación paciente y humilde de las manifestaciones de la naturaleza, que pueden surgir de lo más pequeño y aparentemente insignificante. Como ocurre en esas breves piezas líricas llamadas haiku, la maestría del poeta queda patente en su capacidad para transmitir directamente -sin imprimir la huella de su intermediación- la visualización directa de un instante vivo y unívoco de la vida natural que tiene delante, concretado en una imagen que atrapa la insignificancia del momento y, al mismo tiempo, el misterio de la vida; visibilizando lo invisible.

Kiarostami en Five acota los efímeros ambientes de contemplación del director japonés a tan solo un escenario, una playa. Ahí, imprimiendo la sensación de exterioridad de la cámara característica de Ozu, se sienta con su lente a contemplar la manifestación vital de la naturaleza. Como un haiku, Five eterniza el instante y le da una densidad espiritual. El tributo de Kiarostami a Ozu comienza con el mismo plano de la orilla de una playa con el que este último había concluido Primavera tardía: se trata de un mismo océano sin orilla, aquél en el que todas las imágenes desaparecen. De esta obra nos interesa resaltar una nueva expresión de la imagen más allá de la imagen. Los protagonistas de la tercera toma son un grupo de perros prácticamente inmóviles, situados en una playa, al lado del mar. En ningún momento los perros se distancian demasiado, permaneciendo siempre como una sola unidad. Poco a poco la tonalidad de los colores va disminuyendo, creando un paisaje abstracto. Es un proceso de paso de una imagen real a una imagen abstracta, que transcurre sin que el espectador se percate de ello hasta que vea en la pantalla unas manchas negras que reconoce como los perros gracias al recuerdo, y de la misma manera ocurre con la presencia del mar: va desapareciendo poco a poco, dejando constancia de su existencia en el cuadro por el sonido incesante de las olas, e igual que en los perros, por el recuerdo de aquél que lo observa. Cuando hemos claramente identificado estas formas movedizas, la luz del sol que se levanta las disuelve literalmente en el blanco de la imagen.

Lentamente, la luz del sol se hace tan fuerte que todo lo que podemos ver son pequeños puntos negros: punctum caecum. Poco a poco la tonalidad de los colores va disminuyendo, creando un paisaje abstracto. Es un proceso de paso de una imagen real a una imagen abstracta, que transcurre sin que el espectador se percate de ello hasta que vea en la pantalla unas manchas negras que reconoce como 
los perros gracias al recuerdo, y de la misma manera ocurre con la presencia del mar: va desapareciendo poco a poco, dejando constancia de su existencia en el cuadro por el sonido incesante de las olas, e igual que en los perros, por el recuerdo de aquél que lo observa. La imagen de la toma se funde finalmente en un blanco profundo. Es la idea del sacrificio de la imagen común a ambos cineastas: «Dificultad de ver. Ver no es cosa fácil. Sobre todo, ver bien Ozu. [...] Él renunciará a su derecho a la imagen, lo que va parejo con el abandono de la función misma de la visión. [...] Los ojos abiertos no están en vilo en todo momento ni de manera igual. [...] Los ojos serán entonces aniquilados.» ${ }^{71}$

En el quinto plano y último, y quizá el mejor, el blanco da la luz del día es substituido por el negro nocturno, y toda una noche es representada en 25 minutos. Se ve un reflejo de un reflejo, el de la luna que emerge del agua. Asistimos a una noche de tormenta frente al mar, secuencia en la que en varios momentos la pantalla está totalmente a oscuras, develando así la opacidad del misterio: la «noche luminosa» (šab-i ruwšan) en la que desaparece la percepción sensible. La luna transmite su discurso con apariciones y desapariciones tras las nubes, y la tormenta que se desata, mostrando su descontento e imponiéndose durante unos momentos a los demás presentes gracias a una intensa lluvia y el rugir de los truenos. Vemos el momento en que la luna se cubre de nubes, sentimos -y no vemos, es la noche profunda y sólo tenemos la luz de la luna ahora cubierta por la tormenta. El misterio de la existencia se expresa aquí visibilizando lo invisible.

En resumen, se puede leer, visiblemente, a través de la imagen, un sentido ausente de la imagen. La imagen remite a la presencia-ausencia de lo Real, la Gran Ausencia presente, no-lugar que exige -tal como escribe el cineasta japonés Kijū Yoshida (Yoshishige Yoshida) a partir de la obra de Yasuhirō Ozuun despojamiento total:

«Sólo un prejuicio estúpido puede hacer creer que todas las imágenes deben ser visibles. La imagen que se ve y la imagen que no se ve, que se encuentran en la relación de dos caras de una misma moneda, no presentan sino una diferencia mínima. El espacio de lo invisible creado por la puesta en ausencia de la imagen, es decir, la extensión de su nada, está presente y respira en permanencia alrededor de nosotros. En este sentido, ver y no ver son ni más ni menos equivalentes, y la latitud de la elección de uno o de otro término de la alternancia es el privilegio concedido al cine. Así pues, teníamos buenas razones para estar fascinados por esta imagen presente o ausente que la luz teje y reúne sobre la pantalla.

Lo que está oculto al comienzo de Viaje a Tokio es la revelación de esta ausencia.» $^{72}$

71 Sh. Hasumi, Yasujiro Ozu, París: Éditions de l'Étoile; Cahiers du cinéma, 1998, pp. 215-7.

72 K. Yoshida, Ozu: ou l'anti-cinéma, París: Institut Lumière; Actes Sud; Arte Éditions, 2004, p. 149. 
Del desapego místico de las imágenes y el apagamiento cinematográfico de las imágenes a la desaparición de los cuerpos. Cuerpos impensables. Imágenes-elipsis del otro, del silente. La «mendiga loca» de India Song (1973, Marguerite Duras), que es sólo una sombra que atraviesa la imagen, que «hace diez años que camina», «pregunta el camino para perderse»; la prostituta invisible de Ten (2002, Abbas Kiarostami), que sigue un viaje circular errático, tampoco le vemos nunca el rostro ${ }^{73}$, está fuera de campo y no hay contraplano de ella. Ellas son la imagen sin imagen de la alteridad, del cuerpo excedido hacia un otro de sí, disolviéndose en el espacio ilimitado del totalmente Otro, del silente. Quiebra, deriva, locura de discursos exiliados de sí mismos por una carencia, por Otro.

La presencia in(aparente) del ser. «La forma que lo invisible toma en la mirada es la de su pérdida.»

El sentido transitorio de los estados del alma en su devenir infinito en busca del Uno tendría en el filme experimental de Kiarostami titulado Shirin (2008), una bella expresión. A partir de Husraw wa-Š̀ìñn (fosroes y Shirin), el gran himno sobre el amor del poeta místico persa Ilyās b. Yūsuf Nizāmī (m. 602/1209), Kiarostami construye la película por medio de la inversión del campo escópico: el espectador, el que mira, se convierte en ser percibido, en actor pasivo. Nosotros, desde la butaca, espectadores de fuera, reconstruimos el relato a través de las voces que nos llegan, la música, la iluminación reflejada en los rostros del público y los sonidos de los elementos que intuimos entran en escena. Kiarostami especula con que detrás de Shirin, en forma de espejo contra espejo, la experiencia se multiplica infinitamente, como los grados epifánicos de manifestación del Ser. Kiarostami recrea ahora la rica banda sonora de un filme que nos cuenta una nueva historia de amor trágico en la que, no casualmente, el personaje femenino (Shirin) vuelve a ofrecerse sacrificialmente en aras del amor puro y eterno, de un ideal utópico de libertad y felicidad inalcanzables. Entre el plano y el contraplano inexistente, la historia relatada queda fuera de campo; sólo vemos las facetas de una Realidad que únicamente se manifiesta de forma indirecta por medio de luces y sombras, palabras y sonidos como ecos lejanos del mundo inteligible. La oscuridad de la sala se convierte en el símbolo del mundo de tinieblas de acá abajo sobre la cual se proyectan destellos fugaces del mundo de la Realidad invisible.

$73 \mathrm{El}$ cineasta ya había recurrido a la elipsis de un personaje y a la consiguiente estética del vacío en la larga secuencia del establo subterráneo de El viento nos llevará (1999), en la que, tras veinte segundos de oscuridad, no veremos nunca el rostro de Zaynab, la pudorosa muchacha que la lámpara no alcanza a iluminar. Asimismo, el protagonista del filme, un presunto ingeniero, en un momento fundamental, tiene que ir hasta la cima de una colina para recibir llamadas en su teléfono móvil. Se escucha a alguien cantar: un excavador. A este personaje secundario no se lo verá jamás; aun así, en su extrema invisibilidad funcionará como el signo principal del que surgirán todas las preguntas (morales y filosóficas) del filme. Él y el protagonista conversarán varias veces; en el primer encuentro el ingeniero se topará con un fémur que ha encontrado el excavador. Ahí se cifra el espíritu de la película: el hombre tiene una vida espiritual pero depende de la materia, susceptible de decadencia y determinada por su finitud. En esta dialéctica entre presencia y ausencia, entre ver y no ver, se fundamenta todo el cine de Kiarostami. En las fotografías de exteriores tomadas por el autor desde el interior de un vehículo y a través de los vidrios empañados por la lluvia se articula la misma coincidentia oppositorum entre ver y no ver, entre la visión y la ceguera, entre lo visible y lo invisible. 
Lo invisible en el corazón mismo de la visibilidad. Las figuras que deambulan sin fin en Ten (viaje errático) o que se emocionan al extremo en Shirin (viaje especular) manifiestan formas de amor extremo, desmesurado, en exceso. Shirin es un viaje especular, interior, porque los rostros, espejos del corazón o del alma, manifiestan, cual formas reflejadas en un espejo, los sentimientos, que no vemos, de lo pantalla, el locus del mundo inteligible. En este sentido, cuando en el documental Abbas Kiarostami, verdades e ilusiones (1994, Jean-Pierre Limosin) el cineasta iraní explica que le pidió a su hijo que definiera el amor, éste le respondió: «El amor consiste en amar en exceso». La respuesta le gustó mucho al cineasta, que añade: «Cuando uno ama en exceso, eso se transforma en amor. [...] Cuando alcanza su estado enfermizo, para mí se trata de su última expresión. Por eso nos interesa. Los amores banales no nos inspiran como cineastas. Nos interesan los momentos afectivos extremos y que llegan al extremo». Esta misma respuesta es la que dan los místicos. «Por esta razón - apunta Jean-Luc Nancy-, el cine de Kiarostami es una meditación metafísica [...] el cine como lugar de la meditación». No, por supuesto, como el filósofo aclara, en el sentido de que (necesariamente) las películas del maestro iraní aborden de forma explícita temas metafísicos, sino porque ellas mismas devienen en locus privilegiado de meditación.

París, 27 de septiembre de 2011. Nos hallamos en la Sala Pleyel. En el escenario, el Ensemble intercontemporain (Lucerne Festival Academy Ensemble), bajo la dirección de Pierre Boulez. Entre los instrumentistas, se escucha una de las voces más sobresalientes de la música clásica contemporánea: la soprano canadiense Barbara Hannigan interpretando el texto poético de Mallarmé a partir de la música del propio Boulez. Boulez trabaja en su casa de Baden-Baden rodeado del canto de los pájaros que tanto inspiraba a su maestro - aniquilado en su ultraexigencia-, Olivier Messiaen. Pli selon Pli (1957-62/84/89), portrait de Mallarmé es una obra de Boulez, para soprano y orquesta, basada en poemas de Stéphane Mallarmé ${ }^{74}$. Su composición se inició en 1957; la misma ha tenido varias versiones y varias revisiones hasta 1989. Una primera versión completa (con las cinco partes actuales) fue creada en 1960 en Colonia bajo la dirección del compositor. Una nueva versión fue creada en 1962, también bajo la dirección del compositor. La obra está compuesta de cinco partes. Nos interesa resaltar aquí la segunda parte, la Improvisation sur Mallarmé I: "Le vierge, le vivace et le bel aujourd'hui», porque está basada en el llamado soneto del cisne. El momento de escribir este soneto - uno de los más famosos poemas del autor- publicado en 1885, no se conoce. La mayoría de los comentaristas ven en la imagen del cisne al poeta que lucha contra el «invierno» de la esterilidad. Nosotros nos detenemos en dos líneas del poema, en concreto los términos -blanche agonie (blanca agonía), pur éclat (puro destello)- porque reflejan muy bien lo que, a nuestro entender, podría constituir una declaración de autodisolución, o en términos mallarmeanos de auto(abolición) en la blancura abisal de lo invisible.

En el Guión del filme «Passion» (1982) del cineasta franco-suizo Jean-Luc Godard encontramos su expresión cinematográfica. En este filme vemos al propio realizador que, de espaldas al espectador, acerca sus manos a una luminosa pantalla blanca vacía de imágenes, como si con este gesto pudiera

74 Gf. M. Breatnach, Boulez and Mallarmé: A Study in Poetic Influence, Aldershot; Brookfield: Scolar Press; Ashgate, 1996. 
aprehender lo inaprehensible: «Entonces, crear ese probable, ver, ver lo invisible y ver qué habría si ese invisible fuera visible, que podríamos ver. Ver un guion. Ver, y te encuentras, yo me encuentro, y me encuentro y busco, te encuentras ante lo invisible, esa enorme superficie blanca, la página en blanco, la famosa página en blanco de Mallarmé... Y como un sol demasiado fuerte, la playa... Todo es blanco, no hay ninguna huella...». Mallarmé calificaba su Obertura como «inaprensible».

\section{EL DESLUMBRAMIENTO GIEGO DE LA MIRADA}

En la obra cinematográfica de Godard de los últimos años el recurso a las imágenes sobre las imágenes constituye, en última instancia, un pensar y poetizar por medio de las imágenes (el lenguaje) cuya deriva ontológica desemboca en una evocación de la no-imagen (el enigma de la palabra). En su último filme Adieu au langage (Adiós al lenguaje, 2014), un nuevo poema-ensayo visual, es el dilema que se establece entre «vivir o contar». En estos trabajos, además de la importancia del montaje en todas sus variantes, es frecuente el recurso a la pantalla a oscuras - Histoire(s) du cinéma (1988-98); Dans le noir du temps (2002); Les trois désastres, 2014-, otra forma de hablar del misterio. Allí está el Godard fundamentalmente experimental que trabaja «con el objeto de ver», para «ver no esto o aquello», sino sólo ver si hay algo para ver. En Adiós al lenguaje Godard fuerza los límites de la visión por medio de la estereoscopía del 3d pero, de forma aparentemente paradójica, no para conseguir una mayor definición o resolución de la imagen (high definition, high resolution), sino todo lo contrario, una baja fidelidad (low fidelity) de los paisajes y panoramas en muy baja definición y con los colores sumamente estallados que impiden distinguir con claridad qué es lo que se está viendo: todo ello como reflejo de una realidad que no se deja reducir fácilmente al primado de lo meramente visible. Ello es la expresión del desapego místico de las imágenes que se aprecia en su obra desde la década de los ochenta como manifestación (in)aparente de lo sagrado. Godard y Kiarostami nos ofrecen las expresiones contemporáneas de esa nube/ceguera de la teología medieval akbarí: incognoscible, indiscernible, irrepresentable.

En Adiós al lenguaje Godard alude a una forma de ultra-visión tomando como ejemplo una significativa frase de Marcel Proust que el cineasta atribuye a Claude Monet: «Pintar no lo que vemos, porque no vemos nada, sino pintar lo que no vemos» («Ne pas peindre ce qu'on voit, puisqu'on ne voit rien, mais peindre ce qu'on ne voit pas»). Es la mirada con la que el realizador franco-suizo, en este filme, nos pone a prueba, con la que confronta la ceguera del animal humano. Esa criatura que ya no sabe ver. Para Godard, en esta niebla que nos domina, aposentada en nuestras entrañas y miradas, al menos

queda retratar, como decía Monet, cómo no se ve. La mirada extraviada y prisionera en la mancha ciega, en la indefinición de lo que se percibe.

Una fotografía nos muestra a Claude Monet convaleciente en la cama después de la operación de cataratas, en 1923. Paul Cézanne le dijo a Monet en una ocasión que éste era «solamente un ojo. 
Pero ¡Dios mío, vaya ojo!». A Monet le horrorizaban las teorías y creía que nuestra única manera de entender el mundo era a través de nuestra visión, en vez de a través del intelecto. Su pintura reflejaba este poder de la observación, que se fue volviendo cada vez más fino y selectivo con los años. Pero en 1908, con 68 años de edad, empezó a perder la vista, y ya en 1923 estaba virtualmente ciego. Unas gafas especiales y dos operaciones en su ojo derecho realizadas por su oculista de París, el doctor Coutela, le devolvieron temporalmente la vista. En esta sobrecogedora fotografía del pintor, las gafas correctoras (lente curvada y de color verde para el ojo «bueno»; cristal opaco y plano para el ojo ciego) nos impiden ver sus ojos. La claridad de la ventana junto al lecho no traspasa las lentes que velan por completo sus ojos: oquedad de la mirada hueca, vuelta hacia lo invisible.

«Ciégate hoy mismo: /[...]/ se ahoga lo que ayudó a las imágenes / a pasar el camino por el que vinieron» (Paul Celan, de Atemwende [Cambio de aliento], 1967).

En Los tres desastres (2014), cortometraje que constituye un adelanto de Adiós al lenguaje, Godard introduce numerosas imágenes, planos y secuencias relacionados con los ojos del cuerpo, con el ojo de la cámara (el visor o el objetivo de la cámara cinematográfica como prolongación del ojo del cineasta), el ojo rasgado por el rayo láser en la pantalla del quirófano..., en definitiva, con la visión. Entre esas imágenes cabe destacar tres fotografias en blanco y negro de tres grandes realizadores de la historia del cine: Fritz Lang, Nicholas Ray (en diálogo con el bellísimo primer plano del rostro de la joven Keechie [Cathy O'Donnell] al final de Los amantes de la noche, 1948) y John Ford (retratado por Richard Avedon, 1972), los tres mirando de frente a la cámara; el primero sin el parche para el ojo que también llevó, pero los otros dos con el mismo puesto, con un ojo tapado. De esta forma, a través del ojo cegado, Godard, como Monet, nos invita a la mirada interior, a una inmersión en la visibilidad de lo invisible.

En efecto, siguiendo el ejemplo del pintor francés, Godard sitúa la imagen en el límite entre la videncia y la ceguera: «Cerrar los ojos o no cerrar los ojos [...]». Godard cierra los ojos en lugar de abrirlos: «au moment où il n’y a plus besoin de voir l’image»; «La musique peut m’aider, je suis aveugle, je ne vois rien [...]». Según Merleau-Ponty, el invisible, en realidad, hace posible «la visión misma». Esta visión, de la que tanto el pintor como el poeta dan testimonio, es para Merleau-Ponty voyance. El pensador francés emplea este término numerosas veces en sus últimos trabajos: designa un ver que excede la vista pero que no es lo contrario de la vista, un ver en el cual actividad y pasividad, presente y pasado, percepción e imaginación, mantienen una relación de familiaridad recíproca. Una visión realmente binocular en la cual lo visible sale de los puntos de vista comunes óptico-representativos para recibir relieve y profundidad del fondo de lo invisible, que redobla lo visible y ello con necesidad; una visión en la cual el poeta y el pintor se vuelven voyants únicamente al aceptar el desafío de la ceguera.

Jacques Putman le refirió al poeta francés Charles Juliet la siguiente anécdota de su amigo el gran pintor holandés Bram van Velde, hombre profundamente solitario y callado que se refugiaba en su 
interioridad luminosa, devorada por su hambre de esencialidad. Una vez, saliendo de casa, descubre unas gafas en un contenedor de basura. Se las prueba. Le van bien. Las usa durante veinte años. Pero un día va al oculista. Jacques lo acompaña. Examen de la vista, de las gafas. Estupor del oculista.

- Pero, con estas gafas usted no puede ver nada. Y enseguida:

- Pero, ¿a qué se dedica usted?

Bram se dio cuenta de la sorpresa un tanto burlona del médico y contestó:

-Pinto mi vida interior.

Hasta los cincuenta años, Bram van Velde trabajó en una soledad absoluta, dedicado exclusivamente a pintar, pero sólo cuando sentía que podía hacerlo. Sus primeras exposiciones, cruzada la barrera de los cincuenta, fueron un absoluto fracaso. Cuando la miseria apabullante había llegado al límite extremo de lo que un artista puede soportar se encontró con Samuel Beckett, cuyo primer ensayo en francés después de la Segunda Guerra Mundial -incluido en su libro Disjecta- estuvo dedicado a la pintura de Van Velde, «diría que no abstracta, sino concretamente metafísica». «Todo lo que debiera preocuparnos en la aguda y creciente ansiedad de la relación misma, como si se cerniera sobre ella la sombra cada vez más oscura de una sensación de invalidez, de insuficiencia, de un estado de existencia logrado a costra de todo lo que excluye, de todo lo que impide ver.» A Bram pintar le resultaba muy dificil, porque buscaba eliminar lo accesorio y encontrar la imagen desnuda (nuda essentia animae). Este hombre profundamente melancólico vivía en la más profunda indigencia, prolongación de su ruina interior. La creación artística constituye pues una de-velación de lo invisible, tal como sostiene el pintor: «No es fácil ver.» «Mi pintura es también un aniquilamiento. [...] La vida no está en lo visible. La tela me permite volver visible lo invisible.»

En la obra poética de Rainer Maria Rilke y de José Lezama Lima también encontramos los mencionados recursos mallarmeanos al deslumbramiento y la blancura, a los que se suma la imagen de la ceguera. Tanto en el caso de Mallarmé como en el de Rilke se muestran como imágenes que trasladan al campo de la lírica moderna las especulaciones de la teología negativa. En la poesía de Rilke, el blanco, el silencio, el vacío en la obra, no conlleva negatividad, sino intensidad (gesteigerte Stelle). En la obra del poeta, el deslumbramiento es a la vez el paroxismo y el fin del ver, el desgarrón de lo visible en el instante de mayor intensidad visual. En la mitad de la Quinta elegía el poeta añade unas significativas líneas: «Y sin embargo, a ciegas [blindlings], / la sonrisa...». Esta sonrisa ciega muestra el acontecimiento de la presencia en el corazón de la representación. Es característico de Rilke el que, a través de los motivos de la ceguera y el deslumbramiento, no deje de pensar la imagen a partir de sus límites. En la obra del poeta el «blanco», el espacio dejado en blanco (klar und ausgespart, «claro y reservado») (Sonetos a Orfeo, IV, v. 7) aparece no solamente como la suspensión de la continuidad visible, que abre el espacio (virtual) del acontecimiento (visual) de la aparición, sino como una modalidad del aparecer, una cualidad de intensidad del ser que se manifiesta. Lo que se dibuja a través de todas estas figuras del blanco, es una especie de teología negativa de la imagen, una teoría (y, sobre todo, una práctica) 
específicamente visual del «centro vacío» entendido como intensidad absoluta. Es estos, sin duda, lo que Rilke entiende por lo divino. En un poema de febrero de 1913, Rilke introduce el blanco como una figura de lo absoluto - absoluto que no tiene más que definiciones negativas: es silencioso, inodoro, es una superficie sin fondo (grundlose Fläche) y, sobre todo, no deja señal (nicht Wink). Este blanco por medio del cual el dios se oculta a la compresión visible - pasa y se hunde- es al mismo tiempo la manifestación visual de la intensidad de su presencia, de un «exceso de existencia». El blanco, ¿color universal, color trascendental? En la séptima respuesta a Erika Mitterer (1924), Rilke retoma la autodefinición de la muchacha como blancura única (literalmente: una, unida, einig Weiß). Esta pequeña Farbenlehre rilkeana recuerda un poema mucho más precoz (1990) y simétrico a éste; en la Oración, el poeta se remite a la oscuridad de la noche. Rilke rechaza el dualismo del aquí y el allí, de la substancia y del accidente, de la apariencia y de la verdad, de lo sensible y lo inteligible, de lo concreto y lo abstracto.

La ceguera y el apagamiento de las imágenes también pueden venir expresados por el color negro:

«Un fantasma es aún como un lugar / en que, con ruido, choca tu mirada;

/ pero ahí, en esa piel negra, / tu más fuerte mirar queda disuelto» ${ }^{75}$.

Paul Celan, en el último poema de Reja del lenguaje, que lleva el título de «Engführung» («Angostura»), «Stretto» («estrechamiento», «conducción», etc.): «Hierba, dispersamente escrita. Las piedras, blancas, / con las sombras de los tallos: / ¡No leas más - mira! / ¡No mires más- ve!» ${ }^{76}$ «iNo leas más -mira! / ¡No mires más- ve!», tal es la extraña interpelación que el poeta dirige al lector. «Extraña porque el paisaje-escrito sólo se hace visible en la lectura, y cuando el lector no mira más que la simple presencia de lo escrito, su visión sólo puede quedar cegada por la inmersión en la opacidad de la escritura: las palabras del poema devuelven a quien las lee su mirada vacía, la de aquellos presentes en la separación que encarnan las palabras.» ${ }^{77}$ Pero antes que la escritura y la visión están esas extrañas «piedras, blancas», que es «una extensión hecha de blancura, de vacío [...] el blanco de las piedras es a su vez el blanco de la página» ${ }^{78}$. Asimismo, están los espacios en blanco incrustados en cualquier punto del poema a modo de una escansión silenciosa. Como si la escritura condujera a la lectura a través de la estrechez (Engführung) de un surco o un hiato: «las piedras, blancas» (Celan), «la Blanca casi visible» (María Zambrano, Escritos autobiográficos), «espacio en blanco» (Derrida), «la geografía blanca» (Antonio Gamoneda)... Esta geografía blanca - nieve sobre nieve, blanco sobre blanco (Mallarmé, Gelan, Blanchot, Jabès, Bonnefoy, Gamoneda, Ancet, Noël)- constituye una u-tópica o a-tópica por excelencia, lugar del no lugar.

75 R. M. Rilke, «Gato negro», en Poesía, o.c., p. 271.

76 P. Celan, Obras completas, trad. de J. L. Reina Palazón, Madrid: Trotta, 1999, p. 144.

77 J. M. Cuesta Abad, La palabra tardía. Hacia Paul Celan, Madrid: Trotta, 2001, p. 98.

78 P. Szondi, Estudios sobre Celan, pref. y apén. de J. Bollack, Madrid: Trotta, 2005, p. 52. 
En propiedad, es como Thomas el oscuro, el personaje de Blanchot que mezclaba la mirada con el objeto de la mirada y que era penetrado «en forma de imagen en el momento en que esa mirada era considerada como la muerte de toda imagen ${ }^{79}$.

En los versos de Paul Celan, encontramos el mismo lenguaje paradójico: «Ojos, ciegos al mundo, en las quiebras de la muerte: ya llego, / duro es lo crecido en el corazón.» ${ }^{80}$ «A la ceguera con- / vencidos ojos.» ${ }^{81}$ «Ciégate hoy mismo: / también la eternidad está llena de ojos $\rightarrow »^{82}$.

Perder la vista para convertirse totalmente en visión. El ciego puede ser un vidente, tiene a veces vocación de visionario ${ }^{83}$. La absoluta invisibilidad debe permanecer en el corazón de lo visible ${ }^{84}$. El hombre puede obtener una «visión» espiritual interior a costa de su vista física exterior. Los adivinos son generalmente ciegos, como si conviniese tener los ojos cerrados a la luz física para percibir la luz divina. Tal vez la visión interior tiene por sanción o por condición renunciar a la visión de las cosas exteriores y fugitivas ${ }^{85}$. La ceguera constituye la esencia del ojo ${ }^{86}$. El poeta que reclama estos ojos que ven más allá de lo que hay que ver -ojos, ciegos al mundo, ojos que el habla sumerge hasta la cegue$\mathrm{ra}^{-}$, va en busca de «esta mirada más allá de la mirada, esta visión de ultra-visión» ${ }^{87}$.

«Ojos y boca están tan abiertos y vacíos, Señor.» ${ }^{88}$, según el poema de Celan. «Este sentido oratorio de la poesía de Celan se torna explícito en un poema como Tenebrae, donde de nuevo surgen las imágenes de los ojos y su vaciedad [...]. "Ciégate hoy mismo. / también la eternidad está llena de ojos-”. Como las constelaciones de Miró, los poemas de Celan se llenan de ojos-estrella, sin párpados, vidriosos, desorbitados, inexpresivos. [...] La constelación, el poema es eso visible en lo que se deja entrever algo invisible que se alza detrás del tiempo: “wer / ist unsichtbar genug, / euch zu sehen?”: "¿quién / es

79 M. Blanchot, Thomas el oscuro, o.c., p. 13.

80 P. Celan, «Schneebett» («Lecho de nieve»), Sprachgitter (Reja de lenguaje), en Obras completas, o.c., p. 128. Celan sitúa los ojos en un más allá ontológico. La trascendencia se encuentra más allá de las palabras. Cf. J. Bollack, Poesía contra poesía. Celan y la literatura, Madrid: Trotta, 2005, pp. 193-5.

81 P. Celan, «Tübingen, Jänner» («Tubinga, enero»), Die Niemandsrose (La rosa de nadie), en Obras completas, o.c., p. 162. Las palabras han transportado los ojos a la «orilla» opuesta, la de una videncia en la ceguera. Cf. J. Bollack, ib., p. 177; J. Felstiner, Paul Celan: poeta, superviviente, judio, Madrid: Trotta, 2002, pp. 243-4.

82 P. Celan, Atemwende (Cambio de aliento), en Obras completas, o.c., p. 220.

83 Cf. J. Derrida, Mémoires d'aveugle. L'autoportrait et autres ruines, París: Réunion des musées nationaux, 1990, p. 10. 84 Ib., p. 56.

85 Cf. J.-L. Marion, La croisée du visible, reed., París: Presses Universitaires de France, 1996, pp. 83-115; M.-A. Ouaknin, Lire aux éclats. Éloge de la caresse, París: Lieu Commun, 1989, pp. 285-9; S. Ukai, «L’orient de l’aveugle», en: M.-L. Mallet; G. Michaud (dir.), Jacques Derrida, París: L’Herne, 2004, pp. 348-56.

86 Gf. J. D. Caputo, The Prayers and Tears of Jacques Derrida: Religion Without Religion, Bloomington: Indiana University Press, 1997, índice s.v. «blindness».

87 Ph. Lacoue-Labarthe, La poesía como experiencia, Madrid: Arena Libros, 2006, p. 109.

88 P. Celan, «Tenebrae», en Obras completas, o.c., p. 125. 
lo bastante invisible / para veros?", preguntan unos versos de cambio de Cambio de aliento. Leer en lo invisible es ver en las imágenes la presencia de un instante que-está-por-venir siempre una sola vez y sólo ahora y sólo aquí.»" «El Ojo-Almendra-Nada del Rey [del poema "Mandorla"] se refleja en el Ojo-Almendra-Nada del Hombre como dos espejos vacíos enfrentados. "Dein Aug steht der Mandel entgegen. / Dein Aug, dem Nichts stehts entgegen” (“Tu ojo está en la almendra enfrentado. / Tu ojo a la Nada está enfrentado"). Estos versos de "Mandorla" hacen de la Nada de la que hablan una visión doblemente frontal, la del poema que, ahí enfrente, está (no) viendo y (no) leyendo a quien, ahí enfrente, lo está viendo sin leer o leyendo sin ver: pura, recíproca in-visibilidad de un ojo rasgado por la escritura frente al que toda mirada queda ciega. Lo que esta visión del poema capta ciegamente poco tiene que ver con el "asir con los ojos" (Er-äugen) y el "hacer señas con la mirada" implícitos en el Ereignis $^{90}$, en ese acontecer apropiador o transpropiador que Heidegger designa mediante un término en el que reverbera el sentido metafísico propio del ojo y de la vista, un Sentido del que la visión misma se apropia esencialmente. La mirada del poema puede, en efecto, reflejar la de una Nada anómica y nominal, pero trasluce sobre todo la muerte y la ausencia de un cada-otro singular y masivo al que las palabras querrían corresponder con su concreción material e irrepetible.. ${ }^{91}$

El pintor, como el poeta, privado de la luz, acepta su ceguera, la debilidad del ojo demasiado carnal frente al ojo interior ${ }^{92}$, como la única vía hacia la plena visión: «[Ciégate desde hoy (Paul Celan, Atemwende)]. Pero privarse de ver es todavía una manera de ver. La obsesión de los ojos designa otra cosa que lo visible. ${ }^{93}$ Se llega al ver desde una inmersión en el no ver. Se llega así al punto cero, al punto oscuro que ha de ser iluminado por la ceguera: «[...] La visión coincide con el desvanecimiento de las cosas vistas. [...] Cuanto mayor es la visión, menor es el número de cosas vistas; crece aquélla a medida que se borran éstas.» ${ }^{94}$ La ceguera es la mirada del vidente, del que realmente ve: «Quizás el recurso [...] sea confiarse, más allá de la red del lenguaje (ojo, círculo del ojo entre los barrotes), a la espera de una mirada más amplia, de una posibilidad de ver, de ver sin las palabras mismas que significan la vista ${ }^{95}$. Pero, al mismo tiempo, el poeta emplea la imagen opuesta, la del hombre lleno de ojos como símbolo de la persona que anhela la trascendencia: «enjambres de ojos, oceánicos /[...]/ que nadan hasta cegarse ${ }^{96}$.

89 J. M. Cuesta Abad, Poema y enigma, Madrid: Huerga y Fierro editores, 1999, p. 268.

90 Tal como se expresa Heidegger: «Er-eigen significa originariamente: asir con los ojos (er-äugen), esto es, divisar (erblicken), llamar con la mirada, a-propiar (an-eignen)», M. Heidegger, Identidad y diferencia, trad. de A. Leyte y H. Cortés, Barcelona: Anthropos, 1988, p. 87.

91 J. M. Cuesta Abad, La palabra tardía. Hacia Paul Celan, Madrid: Trotta, 2001, pp. 109-10.

92 Cf. J. Derrida, Mémoires d'aveugle, o.c., p. 24.

93 Cf. M. Blanchot, La bestia de Lascaux; El último en hablar, Madrid: Tecnos, 1999, p. 63.

94 M. de Certeau, La faiblesse de croire, París: Seuil, 1987, pp. 315-6.

95 M. Blanchot, El último en hablar, o.c., p. 55.

96 P. Celan, Los poemas póstumos, trad. de J. L. Reina Palazón, Madrid: Trotta, 2003, p. 283. 
El pensamiento racional-conceptual necesita de la luz para establecer la comprensión del mundo, radicada desde su origen en la visión. Pero iluminar supone quitar al ser toda posible resistencia: la luz abre un horizonte y vacía el espacio. Entrega, pues, el ser a partir de la nada. Hablar, por el contrario, libera a las cosas del dominio de la mirada y, asimismo, exime al propio pensamiento de la necesidad de aproximación a los objetos bajo la dependencia de la luz. Ultra-visión: visión liberada de las limitaciones de la vista. Los ojos que abre la escritura se tornan ciegos al mundo, «yeux aveugles au monde, yeux que la parole submerge jusqu'à la cecité, et qui regardent (ou ont leur place) dans la suit des fissures du mourir» ${ }^{97}$. Forma trascendente de ver, según los versos de Paul Celan citados por el propio Blanchot: «Augen weltblind, / Augen im Sterbegeklüft, / Augen Augen: // Das Schneebett unter uns beiden, das Schneebett.» («Ojos ciegos al mundo, / ojos en las quiebras de la muerte, / ojos ojos: // El lecho de muerte bajo nosotros dos, el lecho de nieve.» ${ }^{98}$

«De este ver potencialmente devorador, hasta los límites de un "éxtasis blanco", Michel de Certeau conocía tanto la fascinación como los peligros; una transparencia cegadora excesiva, la disolución de toda una zona de oscuridad, "de todos los detalles testarudos, las manchas de sombra, los restos de noche" que él amaba. También, el ver místico crea a su vez una escenografía del pensamiento que puede tender al desvanecimiento luminoso y fusional de su objeto, al "ver a Dios, es finalmente no ver $n a d a " » "$ :

«Según lo que escriben [nuestros autores] [...], la visión coincide con el desvanecimiento de las cosas vistas. [...] Afirman que cuanta más visión hay, tantas menos cosas se ven; que una crece a medida que las otras se borran. Por nuestra parte, suponemos que la vista mejora al conquistar los objetos. Para ellos se perfecciona al perderlos. Ver a Dios, finalmente, es no ver nada [...].

Suprima lo que no ve, y suprimirá también lo que sí ve. Entonces se crea un gran deslumbramiento ciego, una extinción de las cosas vistas.

Ver es devorador. $[\ldots]$

Es cierto, es terrible ver. La Escritura dice que no se puede ver a Dios sin morir. Sin duda, con esto quiere decir que ver supone la aniquilación de toda cosa vista. [...]

[...] Una escatología blanca, que suprime y "confunde" todos los secretos. [...]

97 M. Blanchot, Le dernier à parler, Montpellier: Fata Morgana, 1984, p. 15: «Comme s'il s'agissait d'aller vers l'appel de ces yeux qui voient au-delà de ce qu'il y a à voir : yeux aveugles au monde, yeux que la parole submerge jusqu'à la cécité, et qui regardent (ou ont leur place) dans la suite des fissures du mourir.»

98 P. Celan, «Schneebett» («Lecho de nieve»), en Obras completas, o.c., p. 129.

99 Ch. Buci-Glucksmann, «Effets d'ombre: le dernier séminaire», en L. Giard (dir.), Michel de Certeau, París: Éditions du Centre Pompidou, 1987, pp. 169-77, en concreto p. 172. 
Precisamente eso sería el deslumbramiento del fin: una absorción de los objetos y los sujetos en el acto de ver. [...] Una luz sin límites, sin diferencia, de alguna manera neutra y continua. No es posible hablar de esto sino en referencia a nuestras queridas actividades, que allí se aniquilan.

Es comprensible que el miedo se mezcle con la fascinación, entre los caminantes que partieron en busca de la visión. [...] Me imagino que esos peregrinos buscan lo que son porque están seguros de no encontrar. Y de pronto, un buen día, un día enceguecedor, les ocurre. Si salen adelante, en lo sucesivo llevan esa muerte deslumbrada, mudos por haber visto sin habérselo propuesto. [...] Entonces se insinúa la captación de lo que es sin nosotros, la blancura que excede toda división, el éxtasis que mata la conciencia y extingue los espectáculos, una muerte iluminada, un "feliz naufragio", dicen los Antiguos.»" 100

Desde la oscuridad de la noche a la blancura de las azucenas. José Ángel Valente recupera este bellísimo texto de Michel de Certeau:

«Por supuesto, se llega al ver desde una inmersión en el no ver. Se llega así al punto cero, al punto oscuro que ha de ser iluminado por la ceguera. La ceguera es la mirada del vidente, del que realmente ve. Teoría del no ver que está muy bellamente ilustrada en la deposición del padre Martín de San José, quien recuerda cómo, en cierta ocasión, pidiendo a Juan de la Cruz el fraile que le acompañaba que se detuviesen para ver unos palacios ante los que todos se detenían con admiración, él contestó: "Nosotros no andamos por ver, sino por no ver".."101

«Ver es no ver. Entrar en la cegadora plenitud de la luz. [...]

Desde la oscuridad de la noche a la blancura de las azucenas. "Extase blanche".» ${ }^{102}$

Tanto en su poesía como en sus ensayos es frecuente, en la estela de Zambrano y de Certeau, esta teoría del no ver:

«Veo, Veo. Y tú ¿qué ves? No veo. ¿De qué color? No veo. El problema no es lo que se ve, sino el ver mismo. La mirada, no el ojo. Antepupila. El no color, no el color. No ver. La transparencia.» ${ }^{103}$

100 M. de Certeau, «Éxtasis blanco», en La debilidad de creer, Buenos Aires: Katz, 2006, pp. 313-6. (A excepción del término nada, el resto de cursivas son nuestras).

101 J. Á. Valente, Variaciones sobre el pájaro y la red, precedido de La piedra y el centro, Barcelona: Tusquets, 1991, p. 81 n. 5.

102 J. Á. Valente, «Las ínsulas extrañas», La experiencia abisal, Barcelona: Galaxia Gutenberg; Círculo de Lectores, 2004, pp. 71-2.

103 J. Á. Valente, No amanece el cantor, Barcelona: Tusquets, 1992, p. 27. 
El vacío o abismo en el que se hunde o naufraga la mirada aislada de su objeto podrá ser la condición misma del ver y del mirar y se tratará entonces no ya del vacío que aísla sino del hermano del silencio de donde surge el poema y también la visión mística:

«Lo mismo el muro: separa, cierra la visión del más allá, pero está ahí para incitarnos al boquete o simplemente a una visión que penetre y traspase la transparente opacidad del muro, sin ni siquiera romperlo: todo muro es signo de un más allá. Podemos recordar aquí uno de los más bellos poemas de Leopardi, "El infinito": hay un monte y un seto, que al cerrarle al poeta la visión del horizonte extremo provoca en él la visión del infinito. La figuración de un muro que al impedirnos ver hace ver no es tan paradójica como se pudiera pensar: el propio Valente habla de "taladrar el espesor de la luz": la luz, ¿otro muro...? También la luz, "primer animal visible de lo invisible" (cita de Lezama ${ }^{104}$ ), es espacio para la visión e impide ver y puede cegarnos; y uno se puede incluso romper la cabeza contra la transparencia.» ${ }^{105}$

El punto donde no se ve, que cantó José Lezama Lima en su hermoso «Himno para la luz nuestra»: Aunque el oído me da la fe, / la visión como un mastín rastrea / lo que el Arcángel flamea / en el punto donde no se ve.» «El punto donde no se ve-añade fosé Ángel Valente- es el punto donde la visión no es necesaria por ser el punto del que la visión emana y en el que la visión converge.» ${ }^{106}$ «Ojo cegador donde la luz es sólo la extensión» (José Lezama Lima) ${ }^{107}$, «[...] la luz de mis pupilas ciegas» ${ }^{108}$. Hay una «mirada originaria» (Zambrano), una «mirada entrañal» (Valente), pero también una «ciega, obnubilante mirada», «aquello que de sí mismo sus propios ojos no pueden ver» ${ }^{109}$, mirada, en cualquier caso, en el confín con «el fondo insondable de la divinidad» ${ }^{110}:$ «Por supuesto, se llega al ver desde una inmersión en el no ver. Se llega así al punto cero, al punto oscuro que ha de ser iluminado por la ceguera. La ceguera es la mirada del vidente, del que realmente ve.» ${ }^{111}$ La figura de Lázaro tipifica la imposibilidad de la

104 J. Á. Valente, Material memoria, Barcelona: La Gaya Ciencia, 1979, p. 11.

105 A. Ferrari, «El poema: ¿último animal visible de lo invisible?», en J. Ancet (et al.), En torno a la obra de fosé Ángel Valente, Madrid: Alianza, 1996, p. 30.

106 J. Á. Valente, «Carta abierta a José Lezama Lima», en Obras completas II. Ensayos, o.c., pp. 221-2.

107 J. Lezama Lima, «El pez y los ojos», Fragmentos a su imán, o.c., p. 77.

108 J. Á. Valente, «Centro», Fragmentos de un libro futuro, Barcelona: Galaxia Gutenberg; Círculo de Lectores, 2000, p. 98.

109 J. Á. Valente, «Pasmo de Narciso», en Variaciones sobre el pájaro y la red, precedido de La piedra y el centro, o.c., p. 23.

110 Cf. M. Zambrano, «La mirada originaria en la obra de José Ángel Valente» (1981), en C. Rodríguez Fer (ed.), Fosé Ángel Valente, Madrid: Taurus, 1992, pp. 35, 37.

111 J. Á. Valente, La piedra y el centro, o.c., p. 69, n. 4. 
mirada sostenida. Nuestra visión será, por tanto, ciega: «ojo sin mirada» ${ }^{112}$, «el revés de la pupila» ${ }^{113}$, «antepupila», contra-imagen, pero, asimismo, ceguera vidente, sobre-iluminación, ultra-visión.

En el Corpus hermeticum podemos leer: «Pues el sueño de mi cuerpo se había convertido en lucidez de alma; la oclusión (ceguera) de mis ojos en verdadera visión [...]» ${ }^{114}$. El gran maestro persa Farīd al-Dīn 'Aț̣ār (m. 618/1221) sostiene un planteamiento paradójico de la visión similar: «Así me he convertido en un imbécil y en un sabio; uno debe ser un ojo y, sin embargo, no ver; de esta manera, soy un ciego que, no obstante, ve» ${ }^{115}$. «Amigo, aprende de una hormiga lo que es la fuerza del amor; aprende de un ciego el secreto de la visión.» ${ }^{116}$

Arthur Rimbaud el 13 de mayo de 1871 había escrito a Georges Izambard: «Ahora me encrapulo lo más posible. ¿Por qué? Quiero ser poeta y trabajo para hacerme Vidente [...]. Se trata de llegar a lo desconocido por el desorden de todos los sentidos [...]. Yo es otro.» Y, dos días después, a Paul Demeny: «Digo que es necesario ser vidente, hacerse vidente. El poeta se hace vidente por un algo, inmenso y razonado desorden de todos los sentidos.» ${ }^{117}$ «Todo - comenta Valente- se iba deshaciendo en la desnudez absoluta de la visión. Así había entrado, muy pronto, en la videncia, en la luz o el fulgor de la tiniebla donde se forma la ceguera del que ve. En el lugar donde las imágenes se disuelven y al desaparecer destellan. Tal es el punto extremo de la poesía o de la visión.» ${ }^{118}$

La luz no basta para ver, tal como aseguran dos bellos poemas de José Ángel Valente: «engañados los ojos hasta el blanco / candor de la pupila. [...] / / No me basta mirar; / la luz no basta. / Porque he mirado en vano tantas veces, / tantas veces en vano creí ver.» ${ }^{119}$ «Bajé desde mí mismo / hasta tu centro, dios, hasta tu rostro / que nadie puede ver y sólo / en esta cegadora, en esta oscura / explosión de la luz se manifiesta.» ${ }^{120}$

112 M. Blanchot, El paso (no) más allá, Barcelona: Paidós, 1994, p. 107.

113 J. Á. Valente, «Territorio», Interior con figuras, Barcelona: Barral Editores, 1976, p. 7.

114 Hermès Trismégiste, Poimandrès, París: Les Belles Lettres, 1946, t. I, I:30, p. 17. (Trad. cast.: Textos herméticos, Madrid: Gredos, 1999, pp. 96-7.

115 Namūnah-i gazal-i fārsī, ed. de Z. Ḩānlarī, Teherán, 1351 h.sh., p. 19.

116 Ilāhī-Nāme: Die Gespräche des Königs mit seinen sechs Söhnen. Eine mystische Dichtung von Farīdaddīn Attār, ed. H. Ritter, Estambul: Staatsdruckerei; Leipzig: F. A. Brockhaus, 1940, II:3.

117 Cit. J. Á. Valente, «Rimbaud in terra incognita», La experiencia abisal, o.c., p. 62.

$118 \mathrm{Ib}$. (La cursiva es nuestra).

119 J. Á. Valente, «La luz no basta», Poemas a Lázaro, en Poesía y prosa, o.c., pp. 121-2.

120 J. Á. Valente, «Tamquam centrum circuli», ib., o.c., p. 562. 
Esta tradición mística de vincular la visión interior a la extinción de las cosas vistas, al apagamiento de las imágenes ${ }^{121}$, llega hasta la razón poética del pensamiento de María Zambrano, tal como se desprende de los siguientes fragmentos:

«El poeta [místico], perdido en la luz, errante en la belleza, pobre por exceso», «nada en la abundancia, en el exceso... Perdido en la riqueza, ciego en la luz»122.

«Una llama que funde el sentido hasta ese instante ciego con su correspondiente $\operatorname{ver}[\ldots] .{ }^{123}$

«Parece que sea la ceguera inicial la que determine la existencia de los ojos [...]. Y los ojos no son bastante numerosos [...]. El que mira es por lo pronto un ciego que no puede verse a sí mismo. Y así busca siempre verse cuando mira, y a la par se siente visto: visto y mirado por seres como la noche, por los mil ojos de la noche que tanto le dicen de un ser corporal, visible, que se hace ciego a medida que se reviste de luminarias centelleantes. Y le dicen también de una oscuridad, velo que encubre la luz nunca vista. [...]

Y la sombra de esas alas planeará siempre sobre la cabeza del ser que anhela la visión que le ve, y que vela sus ojos cuando, movido por este anhelo, mira. [...]

Y aparecen las alas del Querubín, sembradas de innumerables, centelleantes ojos. Un ser de las alturas, de la interioridad de los cielos de la luz, que aquí sólo en imagen se nos da a ver; alzadas las alas, inclinada la cabeza, imponiendo santo temor al anhelo de visión plena en la luz que centellea en los ojos de la noche.» ${ }^{124}$

En Rilke los ojos poemáticos sólo se simbolizan a sí mismos como unos ojos que giran sobre sí y se vuelven del revés. Es la mirada introvertida de los muertos de que habla el poema «Morgue» (Neuen Gedichte I): «Los ojos, tras los párpados, se han dado / la vuelta, y ahora miran hacia dentro» (Die Augen haben hinter ihren Lidern / sich ungewandt und schauen jetzt hinein. ${ }^{125}$, o la de quienes permanecen ciegos ante «lo abierto» en la octava Elegía: «[...] Nuestros ojos están vueltos / del revés [...]» ${ }^{126}$. Pero este giro hacia

121 Sobre este tema se pueden consultar nuestros artículos: «Ojos aniquilados: ceguera reveladora y apagamiento de las imágenes en el cine de Angelopoulos, Bresson, Kiarostami, Majidi, Sokurov», Convivium. Revista de Filosofia, 22 (2009), pp. 195-218; «El ver que excede la vista en Maurice Merleau-Ponty y Jean-Luc Godard», Convivium. Revista de Filosofia, 24 (2011), pp. 139-62; «El desierto de la no-imagen y las ruinas de la annihilatio en el cine de Kiarostami, Mehrjui y Raisian», Mundo Iranio, 0 (enero 2012), pp. 23-32.

122 M. Zambrano, Filosofia y poesía, o.c., pp. 63-4. (La cursiva es nuestra).

123 M. Zambrano, Claros del bosque, o.c., «La visión - La llama», p. 51. (El subrayado es nuestro).

124 Ib., «Los ojos de la noche», pp. 117-8. (La cursiva es nuestra).

125 R. M. Rilke, Nuevos poemas, ed. bilingüe; trad., intr. y nn. de F. Bermúdez-Cañete, Madrid: Hiperión, 1991, pp. 86-7.

126 R. M. Rilke, Elegías de Duino, ed. bilingüe; trad. y pról. de José M. ${ }^{a}$ Valverde, Barcelona: Lumen, 1980, pp. $74-5$. 
sí da acceso a las imágenes que sólo el poema puede liberar de su confinamiento en una interioridad hueca o abismática. Para Rilke, el acto de ver, en sentido radical, consiste en aceptar la experiencia -el riesgo, la prueba, el desposeimiento- de ser mirado por lo que uno ve ${ }^{127}$.

Según Jacques Lacan: "Hay que entender en este sentido las palabras remachadas en el Evangelio - Tienen ojos para no ver. ¿Para no ver qué? - que las cosas los miran, precisamente.» ${ }^{128}$ Los ojos son ojos igualmente cegados por una ultra-visión. Ojos sacrificados a la luz. Ojos que al ser velados, recuperan la visión, pues ver supone la aniquilación de toda cosa vista: «Ser - escribe María Zambrano- que anhela la visión que le ve, y que vela sus ojos cuando, movido por este anhelo, mira.» ${ }^{129}$ Jaime Gil de Biedma, que visitó a nuestra pensadora en su exilio romano, escribió un poema dedicado a ella: «Cierro / los ojos, pero los ojos / del alma siguen abiertos / hasta el dolor.» ${ }^{130}$ La propia María escribe: «Mira en tu pupila misma dentro // [...] / no llego hasta la Nada.» ${ }^{131}$ Verso semejante al de Paul Celan: «Tu ojo frente a la Nada está.» ${ }^{132}$

El ojo sin iris ni pupila de Léone (C. Th. Dreyer) o los ojos vaciados (Andrei Rublev, A. Tarkovski; Edipo Rey, P. P. Pasolini), son la trasposición al plano cinematográfico de las imágenes rilkeanas de los «ojos tapiados» (vermauerten Augen) de «la ciega» o del «ángel ciego» que mira dentro de sí. En su arriesgada lucha con el ángel, el hombre descubre esta herida, y entonces su fragilidad se hace fuerza. El ángel de los barrancos, de la noche oscura, reorienta su mirada: «la misión del poeta consiste en la esmerada celebración de un ritual que armoniza con la transformación de lo visible en invisible; al celebrar este ritual, el poeta debe ponerse precisamente en el punto de vista del ángel ciego que mira dentro de sí $^{133}$, debe - esto sí- mirar como quien ve en lo invisible» ${ }^{134}$. Rilke recomienda a Hulewicz

127 Cf. K. Winkelvoss, Rilke, la pensée des yeux, París: Publications de l'Institut d'Allemand Université de la Sorbonne Nouvelle, 2004, pp. 6-7.

128 J. Lacan, «¿Qué es un cuadro?», en J. Lacan, El Seminario de Jacques Lacan, Libro 11: Los cuatro conceptos fundamentales del psicoanálisis, Buenos Aires: Paidós, 1987, p. 116.

129 M. Zambrano, Claros del bosque, o.c., p. 118.

130 J. Gil de Biedma, «Piazza del popolo», Las personas del verbo, Barcelona: Seix Barral, 1982, pp. 71-2.

131 M. Zambrano, «Delirio del incrédulo», Tres poemas y un esquema (Jesús Moreno, El Ángel del límite y el confin intermedio), Segovia: Instituto de Bachillerato "Francisco Giner de los Ríos", 1996, pp. 89, 91.

132 P. Celan, «Mandorla», Lectura de Paul Celan: Fragmentos, trad. J. A. Valente, Barcelona: Ediciones de la Rosa Cúbica, 1995, p. 33.

133 Rilke habla de una «equivalencia interior (inneres Äquivalent)»: «En el paisaje español, en Toledo, las cosas externas - torre, montaña, puente- tienen, con una intensidad inaudita, insuperable, una equivalencia interior, tal como uno hubiera querido representárselas. Aparición y visión del objeto se producen a un tiempo, como si a cada objeto correspondiera un mundo interior, como si un ángel, que abarcara todo el espacio, se hubiera vuelto ciego y sólo pudiera mirar dentro de sí mismo.» Cf. A. Pau Pedrón, Rilke en Toledo, Madrid: Trotta, 1997, pp. 6, 59, 60, 76, 110, 111.

134 F. Jesi, Literatura y mito, Barcelona: Barral, 1972, pp. 111, 133, 138. Furio Jesi se hace eco de una carta de 1915 (año que coincide con la preparación de la Cuarta Elegía duinesa), en la cual Rilke explicó su misión poética de representar el mundo según la perspectiva del ángel ciego que mira en su interior. 
compaginar la lectura de las Elegías de Duino con los Sonetos de Orfeo: «Las Elegías y Sonetos se apoyan mutuamente de modo constante: y considero que hay una gracia infinita en que yo, con el mismo aliento, haya podido llenar estas dos velas: la pequeña vela color de herrumbre de los Sonetos, y la gigantesca lona blanca de las Elegías.» ${ }^{135} \mathrm{El}$ ángel es espejo de la cumplida transformación de lo visible en invisible, estadio puro y terrible para nosotros, que todavía dependemos de lo visible. La invoca, la canta, produce su figura, no para constatarla sino para experimentar su fascinante distancia. La mirada del poeta no diseña imágenes-metáforas en las que lo invisible se hace visible, sino al revés, persigue imágenes-figuras que metamorfosean lo visible en invisible, en palabra. Philippe Jacottet ha denominado a estas imágenes-figuras como «images évasives» ${ }^{136}$ en atención a un verso del poema «Infancia: «O Kindheit, o entgleitende Vergleiche» («Oh infancia, oh imágenes que se deslizan»). También Éliane Escoubas ${ }^{137}$ atribuye la imagen-metáfora a la mirada de Narciso, cuya lógica acumulativa intenta retener lo visible, mientras que lo figural sería contemplado por Orfeo, cuya mirada de ángel ciego, que no sabe si camina entre vivos o muertos, lo atrae hacia la vibración fascinante, musical, que da lugar a intensidades y constelaciones nuevas. Ojos ciegos, ojos invertidos por la muerte que es el otro lado de la vida, que abre la mirada a la absoluta incertidumbre. Rilke ama la dificultad de lo incierto y dirige su escritura hacia lo más interior e invisible, intimidad no como encierro sino como penetración del afuera. Las cosas, en el espacio imaginario del poeta, son transformadas en lo incierto, y nos entregan a la desposesión. El poema es el espacio donde la muerte es sabia compañera de la vida, seno de ausencia donde se desenvuelve la incesante metamorfosis de transformar lo visible en invisible.

Ojos de luz calcinados: «[...] Las esquinas más misteriosas, donde los hombres son fantasmas y los fantasmas, espejos.» «[...] Se evaporaron y ardieron como apariciones de lo invisible.» ${ }^{138}$ Ver en la tumba del ojo ¿Puede un «ángel ciego» (Rilke) convertirse en el guía para unos ojos deslumbrados por «la locura de la luz» (Blanchot) ${ }^{139}$ ? ¿Cómo conciliar «la ceguera inicial que determina la existen-

135 R. M. Rilke, Elegías de Duino, o.c., Carta a W. Hulewicz, p. 23.

136 Ph, Jacottet, Rilke, París: Seuil, 1976, pp. 7 y 8.

137 E. Escoubas, «Rilke: les sonnets à Orphée», Imago mundi. Topologie de l'art, París: Galilée, 1986, pp. 330-2.

138 J. Lezama Lima, Cartas (1939-1976), intr. y ed. de E. Lezama Lima, Madrid: Orígenes, 1978, 2 de octubre de 1971; agosto 1974, pp. 234, 258.

139 «locura de la luz» reveladora para Blanchot: «Yo la veo, esta luz fuera de la cual no hay nada». Esa verdad revelada - a través de la locura de la luz- se trata del reconocimiento tajante, duro, descarnado, y al mismo tiempo liberador, de la propia muerte. Es el hombre -encandilado por el resplandor de la fatalidad, a la que decide ver de frente aunque lo enceguezca- el que admite su propia fecha de vencimiento. Lo experimenta Borges cuando dice que «la vida es la muerte que llega». Otra variante de la misma perplejidad aparece en el texto $E l$ instante de mi muerte; allí, un joven a punto de ser fusilado por un pelotón nazi, siente -frente a la inminencia de su desaparición- un repentino e inexplicable arrebato de bienestar a través de la muerte como liberación: «Sé -lo sé- que aquel al que ya apuntaban los alemanes, no esperando más que la orden final, experimentó entonces un sentimiento de ligereza extraordinaria, una especie de beatitud (nada feliz, sin embargo), ¿alegría soberana? ¿El encuentro de la muerte con la muerte? [...] Quizás él era súbitamente invencible. Muerto-inmortal. Quizás el éxtasis. Más bien el sentimiento de compasión por la humanidad sufriente, la dicha de no ser inmortal ni eterno.» M. Blanchot, El instante de mi muerte; La locura de la luz, Madrid: Tecnos, 1999, pp. 19-20. (La cursiva es nuestra). 
cia de los ojos» con la imagen de «las alas del Querubín, sembradas de innumerables, centelleantes ojos» (M. Zambrano)? ${ }^{140}$ «Dichosa muerte, dichosa sepultura» (J.-J. Surin) ${ }^{141}$, «la gran muerte» que sobreviene con la irrupción del ángel de lo invisible (Rilke visionario, en su estancia en Toledo) ${ }^{142}$, «una muerte aurora, señal del sacrificio aceptado» (M. Zambrano)...; esto es, cuando la gruta que se cava en el propio seno, finalmente, abre la visión: «La luz hierve debajo de mis párpados», dice el verso de Antonio Gamoneda ${ }^{143}$; «Mi rostro hierve en las manos del escultor ciego.» ${ }^{144}$ La raíz, por lo tanto, es el miedo, es la contemplación de la muerte, es el miedo de la muerte. Esta es la constante de la escritura del poeta a lo largo de su vida, y configurará lo que él mismo ha definido como su peculiar «poética de la muerte» ${ }^{145}$. La muerte no le importa al peregrino querúbico de Silesius, el caminante absoluto, el andador de la nada, porque de algún modo es la meta de su andadura eterna.

El símbolo poético se parece a la muerte como un rostro a su propia imagen corpórea ${ }^{146}$. Asimismo, se pueden recordar los «ojos tapiados» (vermauerten Augen) de «la ciega» de la obra de Rilke ${ }^{147}$ : «en los ojos tapiados, que no se movían. / [...] / Luego se fue cerrando (cicatrizando) el camino a los ojos.» ${ }^{148}$ En Gong, el poeta escribe también de estos ojos que se cierran, aniquilados en el umbral de la visión: «Hay que cerrar los ojos y renunciar a la boca, / permanecer mudo, ciego, deslumbrado» ${ }^{149}$. A su vez, Valente apunta: «Ciego de ver» ${ }^{150} ;$ «[...] la no visible mano de un dios te borra [...]. Disuelto estás, al fin, en tu propia mirada» ${ }^{151}$; «aniquilada el alma, a la estancia invisible» ${ }^{152}$. «Lo que no ve apunta Maurice Merleau-Ponty- es lo que hace que vea» ${ }^{153}$.

140 M. Zambrano, Claros del bosque, reed., Barcelona: Seix Barral, 1993 [1977], pp. 117-8.

141 J.-J. Surin, «De l'abandon intérieur, pour se disposer à la perfection de l'Amour Divin», Cantiques Spirituels, ed. 1660, cánt. V, 25-26. Cit. en M. de Certeau, El lugar del otro. Historia religiosa y mística, ed. establecida por L. Giard, Buenos Aires; Madrid: Katz, 2007, p. 362.

142 R. M. Rilke, Elegías de Duino, o.c., pp. 13, 21-3. Cf. A. Pau, Vida de Rainer Maria Rilke. La belleza y el espanto, Madrid: Trotta, 2007, pp. 406-7, 409-13.

143 A. Gamoneda, Arden las pérdidas, en Esta luz, o.c., p. 413.

144 A. Gamoneda, Libro del frío, ib., p. 371.

145 A. Gamoneda, preámbulo a Sólo Luz (Antología poética 1947-1998), Valladolid: Junta de Castilla y León, 2000, p. 8.

146 J. M. Cuesta Abad, «Ensayo sobre la desaparición. Símbolo y experiencia en Antonio Gamoneda», en M. Casado (ed.), Cuestiones de poética en la actual poesía en castellano, Madrid; Fráncfort d. M.: Iberoamericana; Vervuert, 2009, p. 107.

147 Cf. J. Derrida, Mémoires d'aveugle, o.c., pp. 44-5.

148 R. M. Rilke, «Die Blinde» (La ciega), El libro de las imágenes (Das Buch der Bilder), ed. bilingüe; trad. de J. Munárriz, Madrid: Hiperión, 2001, p. 221.

149 R. M. Rilke, Poésie, Euvres, 2, ed. de P. de Man, París: Éditions du Seuil, 1972, p. 518.

150 J. Á. Valente, Siete representaciones, en Punto cero, o.c., fragmento VI, p. 241.

151 J. Á. Valente, No amanece el cantor, Barcelona: Tusquets, 1992, p. 87.

152 J. Á. Valente, «Una oscura noticia», El inocente, en Punto cero, o.c., p. 390.

153 M. Merleau-Ponty, Lo visible y lo invisible, seguido de notas de trabajo, Barcelona: Seix Barral, 1970, p. 299. 
Un dicho sufi del maestro persa Bāyazīd de Bistām (m. 260/874) dice: «El tasawrwuf es una luz resplandeciente que ciega los ojos y por la cual ellos ven.» ${ }^{154}$ Según Ibn 'Arabī, la luz es lo que no se puede ver, pero por la cual se ve, tal como ya lo enseña el célebre teólogo, filósofo y místico de origen persa Abū Hāmid Muhammad al-Ghazālī (m. 505/1111) en su Ihȳ̄’ ulūm al-Dīn.

En un kōan sacado del Wu Mên Kuan vemos una perfecta dramatización del proceso con que la articulación se transforma en no-articulación. La anécdota describe vívidamente cómo el monje Tê Shan (en japonés: Tokusan, ca. 782-865), que llegaría a ser más tarde un reputado maestro, alcanzó por primera vez la iluminación:

«Una vez Tê Shan fue a visitar al maestro Lung T’an (en japonés: Ryūtan, ca. 850) para pedirle instrucción y se entretuvo hasta entrada la noche.

T’an dijo: "La noche está avanzada. ¿Por qué no te retiras a descansar?”.

Shan hizo una profunda reverencia, descorrió las cortinas y salió. Pero fuera reinaba una completa oscuridad. Volvió atrás y le dijo al maestro que fuera estaba completamente oscuro.

T’an encendió una vela y se la ofreció. Shan estaba a punto de cogerla cuando, de repente, T’an la apagó.

Shan alcanzó la iluminación en el acto.» ${ }^{155}$

Un drama silencioso. En el último instante crítico, ni una sola palabra. No hay que decir que la luz de la vela que alumbra el mundo de las tinieblas y lo divide en cosas visibles juega aquí el papel del lenguaje en su función esencial de articulación. Cuando el maestro sopló la vela, el mundo un instante iluminado cayó nuevamente en las sombras originales en las que nada podía discernirse. La articulación se anuló y pasó a ser no-articulación. Fijémonos en esto de todos modos: dado que Tê Shan había visto, unos instantes antes, el mundo iluminado (es decir, el mundo articulado), la oscuridad no era de ningún modo oscuridad pura; se trataba de una oscuridad en la que todas las cosas articuladas habían sido tragadas. Se trataba de la no-existencia como plenitud de la existencia.

Esta anécdota ilustra muy bien sentido del empleo del fundido en negro y de la pantalla a oscuras en el cine de Abbas Kiarostami ${ }^{156}$.

154 Véase L. Massignon, Recueil de textes inédits concernant l'histoire de la mystique en pays d'Islâm, París: Geuthner, 1929,33, n. $^{\circ} 20$.

155 Cit. T. Izutsu, «El sentido y el sinsentido en el budismo zen», en Hacia una filosofia del budismo zen, Madrid: Trotta, 2009, pp. 107-8.

156 En cinco secuencias de otros tantos filmes de Abbas Kiarostami encontramos el recurso a la sustracción de la imagen, al campo vacío en forma de pantalla casi a oscuras o fundido a negro. Según un orden cronológico, la primera de ellas es la «noche luminosa» (šab-i ruwšan) de ¿Dónde está la casa del amigo.?, 1987); la segunda, el plano de la luna velada por las nubes y el minuto de negro absoluto y mortal de Ta'm-i gīlās (El sabor de las cerezas, 
Maurice Blanchot lo había contemplado en El espacio literario, uno de sus escritos más relevantes, cuando habla de la imagen:

«La fascinación es la mirada de la soledad, la mirada de lo incesante y de lo interminable donde la ceguera todavía es visión, visión que ya no es posibilidad de ver sino imposibilidad de no ver, la imposibilidad que se hace ver [...].

Ese medio de la fascinación, donde lo que se ve se apodera de la vista y la hace interminable, donde la mirada se inmoviliza en luz, donde la luz es el resplandor absoluto de un ojo que no se ve, y que, sin embargo, no deja de ver porque es nuestra propia mirada en espejo, ese medio es por excelencia atrayente, fascinante: luz que también es el abismo, luz horrorosa y atractiva en la que nos abismamos. [...]

La fascinación está fundamentalmente ligada a la presencia neutra, impersonal, el Uno indeterminado, el inmenso Alguien sin rostro. Es la relación que mantiene la mirada - relación neutra e impersonal- con la profundidad sin mirada y sin contorno, la ausencia que se ve porque ciega.» ${ }^{157}$

En este sentido, en Three Times (Tiempos de amor, juventud y libertad, 2005), bello largometraje del reconocido cineasta taiwanés Hou Hsiao-hsien, la joven cantante Jing no sólo es epiléptica, sino también nacida prematuramente y casi ciega del ojo derecho. En última instancia, esta ceguera incipiente es, como en el caso de la invidencia aceptada de Kiarostami, simbólica del gran fondo indiferenciado que no se deja aprehender, la (in)evidencia del misterio de lo Real, llámese el Uno, Dios, la Nada o el Vacío. Así pues, según Maurice Blanchot, privarse de ver es todavía una manera de ver ${ }^{158}$ :

«Así, aunque tuviera los ojos cerrados, no parecía que hubiese renunciado a ver en las tinieblas; era más bien lo contrario. [...] Era la noche misma. Las imágenes de su oscuridad le anegaban. No veía nada, pero lejos de preocuparse por ello, hacía de esta ausencia de visión el punto culminante de su mirada.» ${ }^{159}$

1997); la tercera, la larga secuencia del establo subterráneo de Bād mā rā jāhad burd (El viento nos llevará, 1999); la cuarta, el largo plano de siete minutos del hotel en el que pernoctan Kiarostami y Samadian en el que una tormenta nocturna les deja sin electricidad y se quedan completamente a oscuras (ABCÁfrica, 2001), y la quinta y última, la noche de tormenta sobre un estanque de Five (2004), secuencia en la que en varios momentos la pantalla está totalmente a oscuras.

157 M. Blanchot, El espacio literario, Barcelona: Paidós, 1992, pp. 26-7. (El subrayado es mío).

158 Cf. S. Zenkine, «Blanchot et l'image visuelle», en M. Antelme (comp.), Blanchot dans son siècle, Lión: Sens Public; Parangon/Vs, 2009, pp. 214-27, en concreto pp. 222-3, 226-7.

159 M. Blanchot, Thomas el oscuro, Valencia: Pre-Textos, 1982, pp. 11, 13. 
De ahí el recurso cinematográfico en Dreyer, Bresson, Godard, Kiarostami, de asociar la muerte con el apagamiento de las imágenes. El empleo frecuente de la pantalla a oscuras en la obra del cineasta iraní Abbas Kiarostami se puede enmarcar en la propia tradición visionaria sufí persa. El cineasta iraní se expresa en similares términos paradójicos:

«La oscuridad durante la película debería ser considerada como la noche en oposición a la luz del día, ausencia en oposición a presencia. A veces, uno debería cerrar sus ojos para ser capaz de ver con su corazón. No ser capaz de ver, en ocasiones es una bendición; un imperativo a fin de ser capaz de ver lo esencial. Hāfez, el gran poeta iraní, dice: "No me estoy quejando de tu ausencia / Sin ausencia cómo podría gozar de tu presencia"..» ${ }^{160}$

Asimismo, en el cine de Carl Theodor Dreyer (el «blanco sobre blanco imposible de filmar»), Robert Bresson (el recurso al fundido en negro), Jean-Luc Godard (la pantalla blanca como «la famosa página en blanco de Mallarmé»), Abbas Kiarostami (la pantalla a oscuras), encontramos este mismo mecanismo del ojo cegado que continúa viendo. Por otra parte, los recurrentes dispositivos del retrovisor (Kiarostami) y del espejo (Hou Hsiao-hsien) remiten a la manifestación (in)aparente del misterio, plenaria aparición velada: respectivamente, la epifanía de lo Real o del vacío.

Después de haber analizado esos elementos que tipifican la ceguera de la realidad sensible en el contexto moderno y contemporáneo - «el punto donde no se ve» (Lezama Lima, José Ángel Valente), «donde la ceguera todavía es visión» (Maurice Blanchot), las gafas sin vidrios graduados como expresión de la extinción del mundo fenoménico (Bram van Velde), la ceguera vidente (Glaude Monet, Paul Celan, Pier Paolo Passolini, Jean-Luc Godard), «el espesor de la luz» que impide ver la otra luz (Maurice Blanchot, José Ángel Valente), el seto que imposibilita ver el infinito (Leopardi), el fundido en blanco, la pantalla a oscuras o el fundido en negro (Abbas Kiarostami, que siempre lleva gafas de sol, incluso en espacios interiores, ¿para poder ver mejor con el ojo interior?)-, es el momento de hacerlo anclándolo en la propia tradición, y más en concreto en la figura que nos ocupa: Ibn 'Arabī, y, en particular, su concepción de las teofanías más allá de las formas o de las imágenes.

\section{EL DESAPEGO MÍSTICO DE LAS IMÁGENES}

Una de las cuestiones principales planteadas a la mística se refiere a la imagen. ¿De qué manera formular lo que nos rebasa? ¿Según qué criterios se puede traducir en los términos de lo visible la experiencia que tiene como horizonte lo invisible? ¿Cómo dar cuenta de lo irrepresentable? ¿A partir

160 J. Porta Fouz (et al.), «Entrevista a Abbas Kiarostami», en A. Cangi (idea y ed.), Abbas Kiarostami. Una poética de lo real, Buenos Aires: Fundación Eduardo F. Costantini, 2006, p. 187. 
de qué analogías describir al Todo-Otro? ${ }^{161}$ Tal como el poeta y ensayista Yves Bonnefoy se cuestiona a partir de la obra del pintor y escultor Alberto Giacometti: «En esa hoja, en ese barro, [Giacometti] malamente puede convocar lo invisible en lo visible. [...] Le dice que la imagen, por muy conmovedora que sea, es la pérdida de la presencia. [...] Que uno anhela ver, claro, pero no de manera total.» ${ }^{162}$ La presencia de la imagen reside así en su propia pérdida, tal como escribe Gilles Deleuze en su libro consagrado a Beckett, L'épuisé: «L'énergie de l’image est dissipative. L'image finit vite et se dissipe, parce qu'elle est en elle-même le moyen d'en finir.» ${ }^{163}$

La capacidad visionaria que se traduce en valoración consciente de la Imagen como tal, es discernible en toda la obra de Ibn 'Arabī. Según el gran maestro andalusí, el conocimiento más elevado de la desnudez absoluta de la Esencia divina está más allá de toda imagen. Él está más allá de cualquier representación, pero también más allá incluso de la ausencia de representación. Las teofanías más allá de las imágenes, que revelan la esencia divina en su completa desnudez, exigen la aniquilación del sujeto, la abolición provisional del yo, que, en el meollo de la experiencia, ignora incluso que está viendo a Dios. Solo puede aprehender ese portentoso hecho una vez que retorna a su conciencia ordinaria. «El que me ve y sabe que me ve, no me ve» (Fut. IV, p. 125). El conocimiento supremo de Dios coincide con la ignorancia absoluta del propio yo, estando reservado para quien, sumido en la noche de su nada original, ha olvidado incluso su propio ser.

En el islam la teología negativa o via negationis (tanzīh) es la vía media que queda expresada en la confesión de fe islámica, «sólo hay un Dios» (Lā ilāha illā $l-L \bar{a} h$ ), que representa en su primer término (lā ilāha, lit.: no hay Dios; el agnosticismo del ta $t \bar{l} l$, Dios desprovisto de todo atributo) la negación absoluta, o sea, el Deus absconditus; mientras que en el segundo término (illā l-Lāh: sino Dios; el asimilacionismo del tašbīh) representa la afirmación absoluta: el Deus revelatus (Non Deus / nisi Deus). Por tanto, la inteligencia primera reconoce que Dios está allende y que ella se constituye en la mismidad (ipseitas), que puede ser dada a conocer a los hombres: el misterio del Dios mostrado. El tanzīh (lit. la «trascendencia»e incomparabilidad divinas, la abstracción), a diferencia del tašbīh (lit. la «similitud», la inmanencia, el antropomorfismo, lo figural), preserva a Dios de toda referencia sensible, de toda cualificación y representación (tawsîff/tamtīll), lejos del alcance de la mirada, en la oscuridad, incognoscible, densa, impenetrable ${ }^{164}$.

161 Cf. A. W. Meddeb, «La imagen y lo invisible. Ibn ‘Arabī: Estéticas», en A. Carmona González (ed.), Los dos horizontes (Textos sobre Ibn 'Arabī). Trabajos presentados al Primer Congreso Internacional sobre Ibn al-'Arabī, Murcia: Editora Regional de Murcia, 1992, pp. 257-79; id., «L'icône mentale», en A. Meddeb (dir.), Le paradoxe des représentations du divin, o.c., pp. 45-66.

162 Y. Bonnefoy, «El deseo de Giacometti», en La nube roja. Diseño, color y luz, Madrid: Síntesis, 2003, pp. 366-7. 163 L'épuisé, en Samuel Beckett, «Quad» et autres pièces pour la télévision suivi de L'épuisé par Gilles Deleuze, París: Les Éditions de Minuit, 1992, p. 77.

164 Gf. A. W. Meddeb, «La imagen y lo invisible. Ibn ‘Arabī: Estéticas», o.c., pp. 260-5; id., «L’icône mentale», o.c., pp. 47-63. 
Tratando de dilucidar en qué dominio existencial acaece la visión inmediata de Dios, es de obligada mención cierta tradición profética, si bien no aceptada por todos los juristas, donde el profeta $\mathrm{Mu}$ hammad declara: «Vi a mi Señor durante el sueño, bajo la figura hermosísima de un joven imberbe, con larga caballera rizada, sentado sobre un escabel, calzados sus pies con áureas sandalias, coronada su cabeza con refulgente diadema que ofuscaba la vista, cubierto su rostro con un velo de albas perlas y envuelto su cuerpo en verde manto.» No obstante, junto a la declaración recién mencionada, también disponemos de la advertencia lanzada por Dios a Moisés, después de que este le implorase, sobre la cima del monte Sinaí, la visión directa, la cual dice así. «No me verás» (7:143). Y, en la misma tónica, leemos en el relato del mismo acontecimiento contenido en el Antiguo Testamento: «No puedes ver mi rostro: porque ningún hombre que me vea, puede vivir» (Éx 33:18-23). ¿Cómo conciliar, pues, ambas declaraciones? Para responder a esa pregunta debemos tener en cuenta que ambos tipos de experiencia denotan estaciones contemplativas distintas. La primera de ellas, encuadrada en el dominio imaginal, y la segunda, perteneciente al mundo de la pura luz; la una, ubicada en el ámbito de las teofanías formales; la otra, en el de las teofanías más allá de la forma.

Según Ibn 'Arabī, cualquier acto de adoración es, necesariamente, un acto de imaginación. Nadie puede adorara Dios si no se lo representa de algún modo, algo que parece contradecir la recomendación meditativa tradicional de trascender imágenes y pensamientos. Ahora bien, la búsqueda deliberada de aquello que está más allá de todo concepto no constituye sino una nueva limitación conceptual. Si Dios es manifiesto y no-manifiesto, exterior e interior, visible e invisible, la dialéctica de la adoración divina estriba en que Él está más allá de cualquier representación, pero también más allá incluso de la ausencia de representación.

Sea como fuere, el proceso de adoración debe desembocar, a la postre, en la visión (ru’ya) directa de la suprema realidad. Pero mucho antes de eso, la perfección de la fe consiste, precisamente, en adorar a Dios como si se le viese, «porque, si no le ves, Él te ve», un consejo que evoca, por cierto, el enunciado coránico: «Las miradas no le ven, pero Él ve las miradas» (6:103).

Ibn 'Arabī se refiere explícitamente a ese tipo de experiencia contemplativa profunda, que trasciende forma e imágenes, cuando escribe:

«Algunos amantes se encuentran sumergidos en estado de embriaguez mística, sin que exista mediación alguna de la conciencia imaginal. Por el contrario, captan un objeto divino incondicionado y no delimitable en el campo cerrado del espacio y la dimensión; son los extáticos puros, análogos a los arcángeles del amor.» ${ }^{165}$

165 Muhyī l-Dīn Ibn 'Arabī, Textos espirituales: Alquimia de la perfecta felicidad y El adorno de los abdâl, Madrid: Sufi, 2004, p. 100. 
Si en el mundo imaginal las ideas asumen forma y, en el plano sensible, adquieren consistencia material, en el reino de los espíritus desnudos de todo substrato tan sólo son luminosidad inmaculada. Sin embargo, para captar dicha luz, es imprescindible transformarse en luz. Y en otro texto, donde insiste en la relación que existe entre la luz y la visión divina, deja bien claro que sólo aquel que es luz puede percibir a Dios, quien es, como expresa el Corán, «Luz sobre luz» y la «Luz de los cielos y la tierra» (24:35).

A pesar de la gran importancia que reviste la imaginación en la cosmovisión akbarí resulta imprescindible no pasar por alto la importante distinción entre teofanías visibles e invisibles, entre teofanías formales y teofanías más allá de la forma. Cuando el Profeta declara que ha visto a su Señor bajo una apariencia hermosísima, se trata, obviamente, de una teofanía encuadrada en el reino de las formas imaginales, donde los significados desnudos se invisten de cualidades sensoriales. Y ese es también el caso de otras experiencias visionarias que tan frecuentes resultan en la biografía de Ibn 'Arabī: pero pecaríamos de un grave reduccionismo si concluyésemos que el reino imaginal constituye el non plus ultra en el conocimiento de Dios y de las realidades suprasensibles. Porque lo único cierto es que, en los escritos del Šayh al-Akbar, no faltan indicaciones de que siempre es posible avanzar más allá. Si él y otros sufies se ocupan principalmente de las teofanías formales es porque resulta más sencillo hablar de ellas ya que, por su misma naturaleza, pueden ser descritas y comunicadas.

Un rasgo fundamental que define a las teofanías más allá de la forma es que conllevan la abolición provisional del yo. Hay que recordar aquí la advertencia bíblica de que nadie puede ver a Dios y seguir con vida, palabras que aluden a un tipo muy especial de muerte mística, la misma que recomienda Muhammad cuando alecciona a sus seguidores a morir antes de morir. Sin embargo, la muerte místico del yo no es privativa del sufismo, sino que es un tópico frecuente en los caminos de transformación espiritual.

Por doquier se repite, con múltiples variantes, la máxima de que, para disfrutar de la vida real, es necesario saborear de antemano la muerte del ego, desde los ecos del «tan alta vida espero que muero porque no muero» de la mística carmelitana, hasta las técnicas psicofísicas del yoga y los estados meditativos más profundos taoístas, budistas o hindúes- que permiten reproducir a voluntad una condición de muerte aparente en la que el sujeto accede a un estado sumamente sutil de cognición. Tal es así que el proceso de la muerte, así como el sueño - del que se afirma que es su hermano menor-, proporciona el modelo por excelencia de los estados unitivos o no-duales de conciencia.

En consonancia con lo anterior, Ibn 'Arabī nos ofrece una explicación más profunda de la declaración que cifra la perfección de la fe en adorar a Dios como si se le viese, donde señala claramente que la condición inexcusable para alcanzar la visión de Dios es la aniquilación del propio yo:

“"¿Qué es el ihsān? (la adoración)” Él respondió: "Que adores a Dios como si le vieses, porque aunque tú no le veas, Él te ve”. Esa última frase comporta una acepción especial para las gentes que perciben los significados 
sutiles, ya que si la cortamos así: fa-in lam takun tarāhu, significa "si tú no eres, le ves (verdaderamente)", lo que vuelve a su sentido: "Su visión no tiene lugar más que por medio de tu propia extinción".»" ${ }^{166}$

Visión de Dios y extinción del yo fenoménico, de la conciencia egoica, van a la par. Se trata, en definitiva, de un conocimiento inmediato que sólo se alcanza cuando desaparece la visión limitada de lo que nunca fue, al tiempo que «trans-aparece» el infinito que siempre ha estado aquí. Por consiguiente, todo lo que podemos hacer para que aflore la realidad última es consumar el estado de aniquilación $\left(f a n \bar{a}^{\prime}\right)$. Tal como afirma el Corán: «Todo aquello que mora sobre la tierra es aniquilado y únicamente subsiste la Faz de vuestro Señor, el poseedor de majestad y generosidad» (55:26-27); «Lo que está con vosotros desaparece, y lo que está con Allāh permanece» (16:96), y «Todo perece salvo Su Faz» (28:88). Lo que nunca ha sido verdaderamente pertenece al dominio de la aniquilación, y lo que nunca ha dejado de ser se refiere al estado de subsistencia. Lo irreal se extingue y sólo resta aquello siempre fue, es y será. Si la aniquilación es el principal atributo de lo que no es Dios, la permanencia le pertenece exclusivamente a Él.

La realidad divina, tal como es en sí misma, resulta demasiado excelsa para que pueda contemplarla ojo limitado alguno, pues sólo Dios ve a Dios. Las teofanías más allá de la forma, que revelan la esencia divina en su completa desnudez, exigen la aniquilación del sujeto que, en el meollo de la experiencia, ignora incluso que está viendo a Dios. Sólo puede aprehender ese portentoso hecho una voz que retorna a su conciencia ordinaria. Así, en uno de sus escritos, refiere Ibn 'Arabī: «El que me ve y sabe que me ve, no me ve.» ${ }^{167} \mathrm{El}$ conocimiento supremo de Dios coincide, de manera tan chocante como ineludible, con la ignorancia absoluta del propio yo, estando reservado para quien, sumido en la noche de su nada original, ha olvidado incluso su propio ser ${ }^{168}$.

En un conocido opúsculo titulado Kitāa al-fanā' fi l-mušāhada [Libro de la extinción en la contemplación]), la Realidad Divina Esencial (al-Haqīqa al-ilāhiyya), que es el fin de la vía del conocimiento metafísico, no puede ser contemplada más que por una realización que es, por una parte, «extinción» (fanā’) de lo que es relativo y contingente en el ser, o en el «ojo» ('ayn) que contempla y, por otra, «permanencia» o «subsistencia» (baqā') de lo que, en éste, es absoluto y necesario ${ }^{169}$.

166 Muhyī l-Dīn Ibn 'Arabī, El libro de la extinción en la contemplación, trad. e intr. de A. Guijarro, Málaga: Sirio, 2007 pp. 61-2.

167 Fut. IV, p. 125. Cit. C. Addas, Ibn Arabī et le voyage sans retour, o.c., p. 62.

$168 \mathrm{Ib}$.

169 Muhyī l-Dīn Ibn 'Arabī, Kitāb al-fanā' fi l-mušāhada, en Rasā’il Ibn al-'Arabī, 2 vols., Hyderabad, 1948. Cf. la trad. franc.: Le Livre de l'extinction dans la contemplation (Kitâbu-l-Fanā’i fi-l-Mushāhada), trad. del ár., pres. y nn. de M. Vâlsan, París: Les Éditions de l'Euvre, 1984; trad. al ingl. de S. Hirtenstein y L. Shamash en fournal of the Muhyiddin Ibn Arabi Society, vol. IX (1991), pp. 1-17; trad. cast.: El libro de la extinción en la contemplación, trad. e intr. de Andrés Guijarro, Málaga: Editorial Sirio, 2007. 
No alcanza el Ser en su absolutidad sino el que lo ha perdido todo: Fa-in lam takun: tarā-Hu, lo que significa: «si tú no eres: (efectivamente) tú Le ves», lo que vuelve al sentido: «Su visión no tiene lugar más que por tu extinción en ti mismo». Para darle un sentido útil al resto de la frase: fa-inna-Hu yarā- $k$, y teniendo en cuanta la consecuencia que implica la conjunción $f a$, el conjunto podría traducirse así: «Si tú no eres, tú Le ves; así pues, en verdad, es Él quien te ve» ${ }^{170}$.

En la obra de Ibn 'Arabī, visión de Dios y extinción de la conciencia egoica van a la par: «¡Reclama la visión y no temas ser fulminado $\left(\operatorname{sa}^{\mathrm{c}} q\right){ }^{!}{ }^{171}$.

Asimismo, se pueden recordar los «ojos tapiados» (vermauerten Augen) del ciego de la obra de Rilke. En Gong, el poeta escribe de estos ojos que se cierran, aniquilados en el umbral de la visión: «Hay que cerrar los ojos y renunciar a la boca, / permanecer mudo, ciego, deslumbrado». El místico es un enmudecido. La misma palabra lo dice: el término «mística» proviene del griego: mystikós, que concierne a los misterios (mystérion), esto es, lo secreto. El mystés, el iniciado en los misterios, era aquel que tenía la boca cerrada. Ambos términos están emparentados con el verbo myô, que significa la acción de cerrar aplicada a la boca y a los ojos, «mantener los labios y los ojos cerrados», «ser silencioso» ${ }^{172}$ (que a su vez proviene de la raíz indoeuropea mu- cuyo significado es el sonido que se hace con los labios cerrados). La certeza mística es pues, etimológicamente hablando, una certeza «con los ojos cerrados». El místico es aquel que no habla porque accede al misterio. Por eso enmudece, «renuncia a la boca» y permanece con los «ojos cerrados», con los «ojos tragados» (Rilke).

Esta des-imaginación akbarí más allá del mundo imaginal requiere lo que el Maestro Eckhart llama Entbildung ${ }^{173}$ (las vías neoplatónicas de la abstracción [aphaíresis, substracción] y de la negación

170 Muḥyī l-Dīn Ibn 'Arabī, Le Livre de l'extinction dans la contemplation, o.c., pp. 48-9.

171 Alusión a la fulminación de Moisés ante la teofanía de majestad en el Sinaí (Cor. 7:143). En el sufismo, la aniquilación mística (fanā') es un requisito previo para la visión de Dios: «Pues el Enviado de Dios ha dicho: "Nadie verá a Dios antes de morir" (Ibn Māğa, fitan, 33).» Fut. III, p. 349. Cf. S. Ruspoli, Le liore des théophanies d'Ibn Arabī, o.c., p. 227 (trad.) y 355-6 (coment.). Cf. J. Nurbakhsh, Simbolismo sufi (Farhang-i Nürbahš, isțtilähät-i tasawreuf), trad. del original farsi por el equipo de traducción del «Centro Sufí Nematollāhi», 8 t., Madrid: Nur, 2003-2010, t. 1 (2003), p. 165.

172 Cf. J. M. Velasco, El fenómeno místico. Estudio comparado, Madrid: Trotta, 1999, pp. 19-20; W. Wackernagel, «L'être des images», o.c., p. 472, n. 60. Para la historia del término ofrece muchos datos H. de Lubac, Corpus


Breve resumen de esa historia en P. Sainz Rodríguez, Espiritualidad española, Madrid: Rialp, 1961, pp. 45 ss. También L. Bouyer, “"Mystique”. Essai sur l'histoire d'un mot», Supplément à la Vie spirituelle, n. 9 (1949), pp. 3-23. B. McGinn constata con todo que una historia adecuada de la palabra mystikós y sus derivados está todavía por hacer.

173 La asociación es de M. Chodkiewicz, «La vision de Dieu selon Ibn ‘Arabī», o.c., p. 166. Cf. W. Wackernagel, Ymagine denudari, o.c., pp. 154-64; id., «L'être des images», o.c., p. 465. 
[apóphasis, denegación] $\left.{ }^{174}\right)^{175}$, o «experiencia interiorizante de denudación de imágenes» ${ }^{176}$. Asimismo, el también místico alemán Enrique Suso (Heinrich Seuse, 1300-1366), cuyo término favorito para referirse al estado de desapego místico era Bildlosigkeit (sin imagen) ${ }^{177}$, sostenía el «empleo de las

174 Sobre los «métodos aphairéticos», o «métodos de abstracción y de purificación intelectual», véanse W. Beierwaltes, Denken des Einen. Studien zur neuplatonischen Philosophie und ihrer Wirkungsgeschichte, Fráncfort del M.: Klostermann, 1985, pp. 129 ss., índice s.v. «Abstraktion»; Ch. Boesel; C. Keller (eds.), Apophatic Bodies. Negative Theology, Incarnation, and Relationality, o.c.; H. G. Coward; T. Foshay (eds.), Derrida and Negative Theology, concl. de J. Derrida, Albany: Sate University of New York Press, 1992, índice s.v. «apophasis», «apophatic», «apophaticism»; M. Gerhart, «The World Image Opposition: The Apophatic-Cataphatic and the Iconic-Aniconic Tensions in Spirituality», o.c., pp. 63-79; P. Hadot, Exercices spirituels et philosophie antique, 2. ${ }^{\text {e }}$ ed., París: Études Augustiniennes, 1987 [1981], pp. 185-8; J. P. Kenney, Mystical Monotheism. A Study in Ancient Platonic Theology, Providence: Brown University Press, 1991, pp. 84-5; B. C. Lane, «Sinai and Tabor: Apophatic and Kataphatic Symbols in Tension», o.c., pp. 189-205; D. J. O’Meara (ed.), Neoplatonism and Christian Thought, Norfolk, Virginia; Albany: International Society for Neoplatonic Studies; State University of New York Pres, 1982, índice s.v. «Apophasis», «Negative theology»; R. Mortley, «Negative Theology and Abstraction in Plotinus», American fournal of Philology, n. 96 (1975), pp. 363-77; id., From Word to Silence, 2 vols. (vol. 1, The Rise and Fall of Logos; vol. 2, The Way of Negation, Christian and Greek), Bonn: Hanstein, 1986; id., «The Name of the Father Is the Son», en R. Wallis; J. Bregman (eds.), Neoplatonism and Gnosticism, Albany: State University of New York Press, 1992, pp. 239-52; M. A. Sells, Mystical Languages of Unsaying, Chicago; Londres: The University of Chicago Press, 1994, en concreto caps. 1, 7: «Awakening without Awakener: Apophasis in Plotinus», «Porete and Eckhart. The Apophasis of Gender», pp. 14-33, 180-205; Ch. M. Stang, Apophasis and Pseudonymity in Dionysius the Areopagite, Oxford: Oxford University Press, 2012; D. Turner, «Apophaticism, idolatry and the claims of reason», en O. Davies; D. Turner (eds.), Silence and the Word. Negative Theology and Incarnation, Cambridge: Cambridge University Press, 2002, pp. 11-34, índice s.v. «apophasis»; J. Whittaker, «Neopythagoreanism and Negative Theology», Symbolae Osloenses, n. ${ }^{\circ}$ XLIV (1969), pp. 109-25 (= Studies in Platonism and Patristic Thought, Aldershot: Ashgate, 1984, art. IX); id., «Arrêtos kai akatonómastos», en H.-D. Blume; F. Mann (eds.), Platonismus und Christentum. Festschrift fï Heinrich Dörrie, Münster: Aschendorffsche Verlagsbuchhandlung, 1983 (ib., art. XII); id., «Epékeina noû kaì ousías», Vigiliae Christianae, vol. 23, n. 2 (1969), pp. 91-104 (id., art. XIII) ; H. A. Wolfson, «Negative Attributes in the Church Fathers and the Gnostic Basilides», Harvard Theological Review, n. 50 (1957), pp. 145-56; E. R. Wolfson, Giving Beyond the Gift, o.c., índice s.v. «abstraction, «apophasis», negative theology».

175 Cf. V. Lossky, Théologie negative et connaissance de Dieu chez Maître Eckhart, París: Librairie Philosophique J. Vrin, 1998, índice s.v. «Abgeschiedenheit», «abstraction, abstrait», «apophase».

176 L. Massignon, La passion de Husayn Ibn Mansûr Hallâj, martyr mystique de l'Islam exécuté à Bagdad le 26 mars 922. Étude d'histoire religieuse, 4 t., París: Gallimard, 1990 [1975], t. I, p. 21.

177 Cf. J. F. Hamburger, The Visual and the Visionary. Art and Female Spirituality in Late Medieval Germany, New York: Zone Books, 1998, p. 203. 
imágenes para expulsar las imágenes» ${ }^{178}$ (daz man bild mit bilden us tribe $)^{179}$. Si el la mística alemana del siglo XIII el Maestro Eckhart habla de la «imagen sin imagen» (bîld âne bîld) de Dios, un siglo antes el gran místico persa Farīd al-Dīn 'Aț̣ār (m. ca. 618/1221) se refiere a la Realidad divina en similares términos a las teofanías akbaríes más allá de las formas o de las imágenes: no-imagen, per. naq̌̌-bi$n a q \check{s}$, bi-șürat, bi-nišān ${ }^{180}$ (cf. el mencionado Bildlosigkeit de Enrique Suso), i.e., la imagen original del mundo Invisible. En el Mușībat nāma, 'Aț̣ār hace referencia a esta des-imaginación eckhartiana de las imágenes: «iOh tú retenido en tu propia masa, tú que veneras tus fantasmas, sabe que el Ser está más allá de tu imaginación $[\ldots]{ }^{181}$.

En este sentido, el «programa de abstinencia» con el que el pintor Ad Reinhardt mostraba su interés por la teología negativa, tiene una bella concepción en el concepto islámico del tağrìd (desapego, desprendimiento, desposesión, despojamiento, aislamiento, abstracción) (cf. la abegeschiedenheit, «desapego», abandono o despojamiento espiritual de la mística renana ${ }^{182}$ ): tanto en el sentido teológico del Dios gayr muğarrad - esto es, gayr (el «otro»); muğarrad («el despojado, el abstracto, el puro

178 Enrique Suso explica que utiliza imágenes, que «habla en imágenes» de lo que «está por encima de todos los sentidos y por encima del intelecto humano». Su problema es, pues, preciso: ¿«Cómo imaginar sin imágenes (bildlos gebilden) y modalizar sin modos (wiselos bewisen)», es decir, también «formar sin formas y probar sin pruebas» lo que carece de imagen y modo, «forma sin forma y modo sin modo», según la frase de san Bernardo? La respuesta evoca el punto de paso de la teología simbólica y afirmativa a la teología negativa y mística: hay que «expulsar la imagen por la imagen» (bild mit bilden us triben). Como señala acertadamente Alois M. Haas, hay ahí un «programa literario». Si la Vida es menos una mixtificación que una mistagogia, todo el conjunto de la obra se lee como una producción de imágenes (mit bildgebender wise), de metáforas productoras de imágenes (bildgebender glichnus) destinadas a la consumación final en el «sin imagen». Ahora bien, la superación de la imagen, el Entbildung, es, desde Eckhart, la palabra clave de la mística renana. La imagen, la imaginería, está destinada al «que comienza». No tiene ya razón de ser cuando el abandono ocupa el lugar del «buen comienzo». Cf. A. de Libera, Eckhart, Suso, Tauler y la divinización del hombre, Palma de Mallorca: José J. de Olañeta, 1999, p. 55.

179 H. Suso, La vida del siervo. La edición estándar de los escritos vernáculos es Heinrich Seuse: Deutsche Schriften, ed. de K. Bihlmeyer, Stuttgart, 1907; reimpr.: Fráncfort d. M.: Minerva, 1961. Este pasaje es de Leben Seuses, cap. 53 [191 línea 9]. Cit. B. McGinn, «Theologians as Trinitarian Iconographers», en J. F. Hamburger; A.-M. Bouché (eds.), The Mind's Eye. Art and Theological Argument in the Middle Ages, Princeton: Department of Art and Archaeology, Princeton University in association with Princeton University Press, 2006, p. 199. «Pero el más allá de la imagen, que no está "más allá", que está sobre el límite, está en la Bildung del Bild mismo, y entonces al ras del Bild, al nivel del trazado de la figura, el trazamiento, la incisión separante-uniente [...]». J.-L. Nancy, «L'offrande sublime», en J.-F. Courtine (et al.), Du Sublime, París: Belin, 1988, p. 61.

180 No-imagen, per. naqš-bi-naqšs, bi-surat, bi-nišān, i.e., la imagen original del mundo Invisible. Cf. Farīd al-Dīn 'Attār, Le Livre des Secrets (Asrār-nāma), trad. del per. de Ch. Tortel, París: Les Deux Océans, 1985, índice s.v. «nonimage». "A veces él destruye su propia imagen; la rompe con el fin de afirmar la trascendencia del Amado.» Ǧalāl al-Dīn Rūmī, The Mathnawi of Jalálu'ddin Rúmí, ed., trad., coment. y nn. críticas de R. A. Nicholson, 8 vols., Londres: E. J. W. Gibb Memorial Series, Luzac and Co., 1925-1940, II:60.

181 Farīd al-Dīn 'Aț̣āar, Le Livre de l'épreuve (Mușībat-nāma), trad. del per. de I. de Gastines, París: Fayard, 1981, cap. 40 , p. 329.

182 Gf. R. Schürman; J. D. Caputo, Heidegger y la mística, Córdoba, Argentina: Ediciones Librería Paideia, 1995, pp. 20-3. 
en sí»): el Dios despojado de todo atributo, desposeído de toda calificación, desnudo en sí, absoluto, abstracto-, como en el sentido psicológico, es decir, el alma liberada de la impresión de las formas existentes que impiden la recepción de las epifanías del Verdadero. En la terminología de la mística eckhartiana su correspondencia sería el desprendimiento (Entwerden), el «despojamiento» o «desapropiación», el vaciamiento de uno mismo (Entbilden) y la consiguiente «desposesión», la «desapropiación» de las imágenes, la «des-representación» o «des-imaginación» (Entbildung), para finalmente experimentar la plenitud de $\operatorname{Dios}^{183}$.

Lao zi (m. 531 a. C.) ya lo había dejado escrito en el Dao de jing que le contempla sin verle, es el Invisible, la Forma sin forma, la Figura sin figura: «Míralo y no lo verás, se llama invisible. [...] Es decir forma de lo informe, imagen de la inmaterialidad; es decir vaguedad indistinta.» ${ }^{184} \mathrm{Y}$ dos capítulos antes: «el santo favorece el vientre y no el ojo, rechaza éste y elige aquél.» ${ }^{185}$ El Dao es la Gran Imagen sin imagen («la imagen más grande no tiene forma» [da xiang wu xing] ${ }^{186}$ ), lo cual permite multiplicar las imágenes y no dejarse aprisionar por ninguna fascinación. En palabras de Wu Yun: «Por eso el hombre de bien rechaza los deseos y abandona visión y oído ${ }^{187}$, ve lo Sin-forma, oye lo Sin-nombre. Quieto y apacible ${ }^{188}$, perfectamente puro, su cuerpo está en armonía con la pureza de su espíritu. Vacío y desierto, olvida su cuerpo y se une a la esencia suprema.» ${ }^{189}$ Otro procedimiento consiste en meditar sobre diferentes aspectos y formas del vacío: el vacío de su propio ego compuesto por múltiples elementos cuya unidad es artificial; el vacío «del origen de las cosas»: si dicho origen tiene existencia, ¿cuál es su origen? Y, si no es nada, él, entonces está vacío y ¿de dónde pudo surgir este vacío y cómo es posible que de él pueda haber surgido algo?

Como en el desierto, también el Mar de la Realidad divina (la no-imagen, el no-signo) es donde todas las imágenes de este mundo desaparecen ${ }^{190}$, tal como expresa 'Aț̣ār en los siguientes versos del Asrā $r$ nāma (El libro de los secretos):

183 W. Wackernagel, Ymagine denudari, o.c., p. 156; id., «L'être des images», o.c., pp. 455-72.

184 Lao zi, Libro del curso y de la virtud (Dao de jing), ed. y trad. del chino de A.-H. Suárez, Madrid: Siruela, 1998, cap. XIV, p. 57.

185 Ib., cap. XII, p. 53.

186 Id., cap. XLI, p. 111. «Aténte a la gran imagen» (zhi da xiang), id., cap. XXXV. Se trata del curso, de imagen inimaginable (ver los capítulos XIV, «imagen de la inmaterialidad»; y XLI, «la imagen más grande no tiene forma»). Cf. T. Izutsu, «Between Image and No-Image: Far Eastern Ways of Thinking», o.c., pp. 427-61; id., Sufismo y taoísmo. Estudio comparativo de conceptos filosóficos clave, trad. de A.-H. Suárez, 2 vols., Madrid: Siruela, 1997, vol. II: Laozi y Zhuangzi, p. 114; F. Jullien, La gran imagen no tiene forma, o, del no-objeto por la pintura, o.c.

187 Inspirado en Zhuang zi.

188 Inspirado en Lao zi.

189 I. Robinet, Lao zi y el Tao, Palma de Mallorca: José J. de Olañeta, 1999, pp. 176, 180.

190 Cf. A. Gonzalo Carbó, «El desierto de la no-imagen y las ruinas de la annihilatio en el cine de Kiarostami, Mehrjui y Raisian», o.c., pp. 23-32. 
«en el Mar, en efecto, nunca la imagen sensible ha subsistido

Aquel que por imagen ha aceptado la no-imagen

como los Hombres ha renunciado a esta iconolatría

Si concibes la no-imagen y el no-signo

posees la (verdadera) vida» ${ }^{191}$

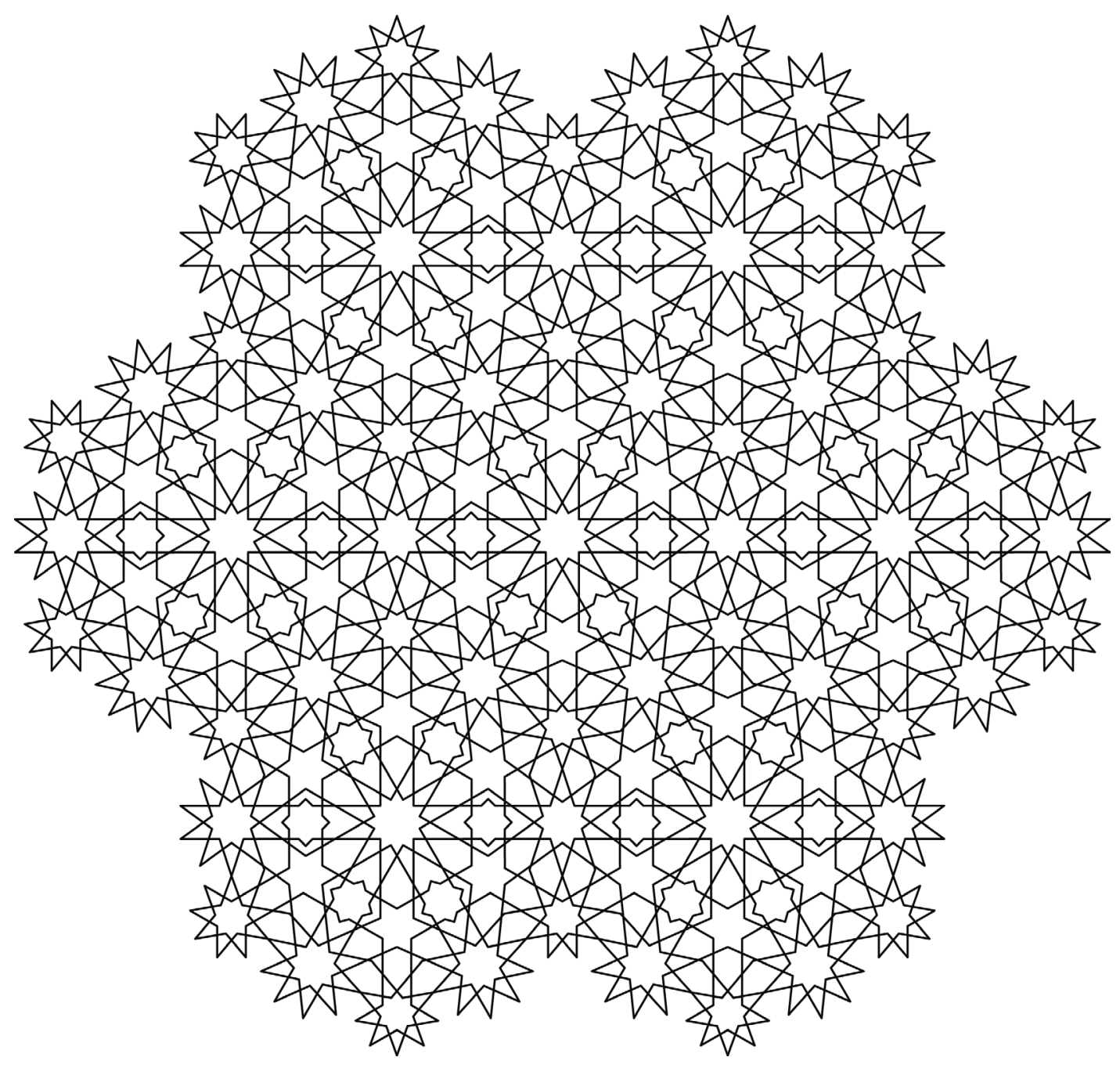

191 Farīd al-Dīn 'Aț̣ār, Le Livre des Secrets (Asrār-Nāma), o.c., vv. 1130-2 [trad. cast.: El libro de los secretos, trad. de C. Janés; S. Garby, Madrid: Mandala, 1999, p. 71]. 